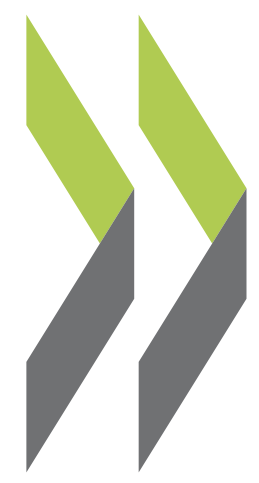

OECD Economics Department Working Papers No. 1645

Reducing socio-economic differences between Gabriel Machlica municipalities in Israel 


\section{ECONOMICS DEPARTMENT}

\section{REDUCING SOCIO-ECONOMIC DIFFERENCES BETWEEN MUNICIPALITIES IN ISRAEL}

\section{ECONOMICS DEPARTMENT WORKING PAPERS No. 1645}

By Gabriel Machlica

OECD Working Papers should not be reported as representing the official views of the OECD or of its member countries. The opinions expressed and arguments employed are those of the author(s).

Authorised for publication by Alvaro Pereira, Director, Country Studies Branch, Economics Department.

All Economics Department Working Papers are available at www.oecd.org/eco/workingpapers.

JT03469856 
OECD Working Papers should not be reported as representing the official views of the OECD or of its member countries. The opinions expressed and arguments employed are those of the author(s).

Working Papers describe preliminary results or research in progress by the author(s) and are published to stimulate discussion on a broad range of issues on which the OECD works.

Comments on Working Papers are welcomed, and may be sent to the Economics Department, OECD, 2 rue André-Pascal, 75775 Paris Cedex 16, France, or by e-mail to econ.contact@oecd.org.

All Economics Department Working Papers are available at www.oecd.org/eco/workingpapers

This document and any map included herein are without prejudice to the status of or sovereignty over any territory, to the delimitation of international frontiers and boundaries and to the name of any territory, city or area.

The statistical data for Israel are supplied by and under the responsibility of the relevant Israeli authorities. The use of such data by the OECD is without prejudice to the status of the Golan Heights, East Jerusalem and Israeli settlements in the West Bank under the terms of international law.

○ OECD (2020)

You can copy, download or print OECD content for your own use, and you can include excerpts from OECD publications, databases and multimedia products in your own documents, presentations, blogs, websites and teaching materials, provided that suitable acknowledgment of OECD as source and copyright owner is given. All requests for commercial use and translation rights should be submitted to PubRights@oecd.org 


\section{Abstract/Résumé}

\section{Reducing socio-economic differences between municipalities in Israel}

Despite being one of the smallest countries in the OECD, Israel is marked by significant socio-economic disparities, which have a clear spatial dimension. Ethnic and religious groups with weak socio-economic outcomes are not benefitting from the thriving high-tech sector in the centre of the country. As a result, there is a persistent lack of employment opportunities in the peripheral areas alongside skills shortages in the dynamic centre. Inequalities between municipalities are the highest in the OECD. Moreover, the current pandemic has hit poorer Haredi neighbourhoods particularly hard. The government should reduce barriers that prevent segments of the population from fully participating in the economic process and give everyone a similar chance to succeed, regardless of where he or she was born. This will require equal access to high-quality education, affordable housing, reasonable public transportation and improved urban planning in every municipality to reduce spatial divides and segregation of disadvantaged households. Local authorities can play a significant role, since good municipal government and effective policies to achieve national priorities are the best means to improve the outcomes of residents of poor areas.

This Working Paper relates to the 2020 OECD Economic Survey of Israel http://www.oecd.org/economy/israel-economic-snapshot/

Keywords: Israel, regional inequality, municipalities, fiscal decentralisation, education, infrastructure, housing

JEL Classification: H52, H53, H54, H71, H72, H77, O18, R11, R52, R58

\section{Réduire les disparités socioéconomiques entre les communes en Israël}

Bien qu'il soit un des plus petits pays de l'OCDE, Israël se caractérise par d'importantes disparités socioéconomiques, qui ont clairement une dimension spatiale. Les groupes ethniques et religieux dont les résultats socioéconomiques laissent à désirer ne bénéficient pas de l'essor du secteur des hautes technologies observé dans le centre du pays. En conséquence, on observe un manque persistant de perspectives d'emploi dans les régions périphériques, conjugué à des pénuries de compétences dans le centre dynamique du pays. Les inégalités entre communes sont les plus marquées de la zone OCDE. En outre, la pandémie actuelle a touché de manière particulièrement dure les quartiers haredi défavorisés. Le gouvernement devrait réduire les obstacles qui empêchent certains segments de la population de participer pleinement à la vie économique, et donner à chacun des chances de réussite similaires, indépendamment de son lieu de naissance. Cela passe par une égalité d'accès à un enseignement de qualité, des logements abordables, une offre raisonnable de transports publics et une amélioration de l'urbanisme dans chaque commune, permettant de réduire les fractures territoriales et la ségrégation des ménages défavorisés. Les collectivités locales peuvent jouer un rôle important à cet égard, étant donné qu'une bonne administration communale et des mesures efficaces pour concrétiser les priorités nationales constituent les meilleurs moyens d'améliorer la situation des résidents des zones défavorisées.

Ce document de travail est lié à l'Étude économique de l'OCDE de 2020 consacrée à Israel http://www.oecd.org/fr/economie/israel-en-un-coup-d-oeil/

Mots clés : Israël, inégalités régionales, municipalités, décentralisation fiscale, éducation, infrastructure, logement

Classification JEL : H52, H53, H54, H71, H72, H77, O18, R11, R52, R58 


\section{Table of contents}

\section{Reducing socio-economic differences between municipalities in Israel}

Differences between municipalities and localities are pronounced 6

Improving transport infrastructure to spur growth in lagging municipalities 10

The transport infrastructure and public transport network need to expand 12

$\begin{array}{ll}\text { Enhance the effectiveness of infrastructure governance } & 14\end{array}$

Improving the economic policy framework for the housing market 16

Municipalities favour business development over residential growth 17

$\begin{array}{ll}\text { More incentives for residential development should be provided } & 19\end{array}$

More support should be provided to Arab-Israeli municipalities 20

Expanding social housing in economic centres $\quad 21$

Regional development policy should continue to free up public land in the centre 22

Low skills can be another barrier to growth in lagging localities 23

Reducing the skills gap between regions should start early on $\quad 25$

$\begin{array}{ll}\text { Improving teacher quality in poorer regions } & 27\end{array}$

$\begin{array}{ll}\text { Building bridges between different educational streams } & 28\end{array}$

The local authority funding system exacerbates regional differences $\quad 29$

Economically strong municipalities benefit from high local revenues $\quad 29$

Central government transfers are too small to close local revenue gaps 31

The local fiscal framework needs to promote high-quality services in poorer municipalities $\quad 34$

$\begin{array}{ll}\text { References } & 38\end{array}$

\section{Tables}

Table 1. Responsibilities of MTAs (high, partial, no responsibility) 15

Table 2. The impact of grants on fiscal disparities among Israeli local governments, $2016 \quad 32$

Table 3. Recommendations for reducing differences between municipalities in Israel 37

\section{Figures}

$\begin{array}{ll}\text { Figure 1. Income disparities among localities are high } & 7\end{array}$

Figure 2. Disparities in disposable income have been widening $\quad 8$

Figure 3. Arab-Israeli and Haredi cities are much poorer 9

Figure 4. Haredi towns have been particularly hit by the pandemic $\quad 10$

Figure 5. Israel's current core infrastructure stock lags significantly behind other countries' 11

Figure 6. The supply of transport infrastructure has not been sufficient to meet rising demand 11

Figure 7. The accessibility to public transit is weak, particularly in peripheral areas 12

Figure 8. Traffic intensity is significant in Israel $\quad 14$

Figure 9. Transport regulation is heavy in Israel $\quad 16$

Figure 10. Housing costs are high for poor households $\quad 17$

Figure 11. Newly built houses are increasingly tilted towards large-size and luxury housing 18

Figure 12. Umbrella agreements assume significant population increase in poorer municipalities 19 
Figure 13. There is much less land per capita in Arab-Israeli municipalities 20

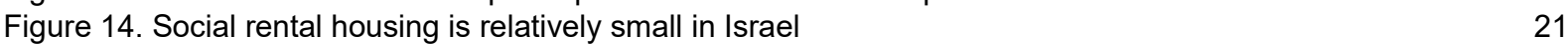

Figure 15. Social housing is located mostly in areas with weak economic activity 22

Figure 16. Extent of change in population aged 15-29 during the decade 2005-15 23

Figure 17. Poorer socio-economic areas have less skilled labour $\quad 24$

Figure 18. Education spending is much lower in the poorer localities $\quad 25$

Figure 19. Students who attended pre-school education are less likely to become low-performers 26

Figure 20. Schools in poorer localities have weaker teachers 27

Figure 21. Local tax autonomy in Israel is weak $\quad 29$

Figure 22. Local authority revenues are much smaller in poorer municipalities $\quad 30$

Figure 23. Poorer municipalities have weaker tax collection 30

Figure 24. The differences between municipalities remain large even after transfers $\quad 32$

Figure 25. Poorer municipalities have less public-service provision $\quad 33$

Figure 26. Municipalities with disadvantaged groups have much worse fiscal outcomes ${ }^{1} \quad 33$

Figure 27. Comparison of equalisation systems $\quad 35$ 


\title{
Reducing socio-economic differences between municipalities in Israel
}

\author{
By Gabriel Machlica ${ }^{1}$
}

\section{Differences between municipalities and localities are pronounced}

Israel is one of the smallest countries in the OECD in terms of surface area but suffers from large economic disparities. Income inequality and poverty rates are higher than the OECD average and have clear spatial dimensions, as poor households are regionally concentrated. Israel has a single sub-national level of government, composed of 257 local authorities. The average monthly wage in the richest locality is almost four times higher than in the poorest one (Figure 1, Panel A). The difference in disposable income between the poorest locality and the richest one is one of the largest in the OECD (OECD, 2018a). Only a tenth of Tel Aviv's residents lives below the poverty line, while in Jerusalem almost half of residents do so (Panel B). Regional disposable income differences are the largest among OECD countries, even after controlling for the average level of the Gini coefficient (Panel C).

Income disparities between the richest and poorest areas continue to widen. The growth in disposable income has been largely confined to wealthier localities. Over the last decade the income disparity between the top $10 \%$ and the bottom $10 \%$ of regions grew by an annual average of more than $5 \%$ - the fastest pace among the OECD countries (Figure 2). This suggests that not every area has been benefitting from the country's robust economic performance before the crisis.

The current economic impact of the crisis will differ across regions. In the short run, the most touristic destinations and metropolitan regions will be at higher risk of employment losses than other regions. At the same time, the first phase of the outbreak disproportionally affected poorer Haredi neighbourhoods (Box 1). However, in the medium- to long-term the economic effect is likely to become more uniform across regions (OECD, 2020a) and disparities between municipalities are expected to remain large.

The differences between municipalities and localities are due to significant divisions that exist in the Israeli economy and society. To begin with, the labour market is marked by severe duality, with a significant, highly productive high-tech sector mainly consisting of telecommunications and software companies in the centre and mostly low-productivity, often non-tradable sectors, with low-quality and low-wage jobs in the

\footnotetext{
${ }^{1}$ Gabriel Machlica (gabriel.machlica@oecd.org) is an economist in the Economics Department of the OECD. The author would like to thank Alvaro Pereira, Isabell Koske, Patrick Lenain, Mame Fatou Diagne, Nicola Brandt, Oliver Roehn, Daniela Glocker, Bloechliger Hansjoerg, Kass Forman (all OECD Economics Department), Peter Jarrett (consultant), Bert Brys (OECD Centre for Tax Policy and Administration) and Isabelle Chatry (OECD Centre for Entrepreneurship, SMEs, Regions and Cities) for useful comments and suggestions. The paper has also benefitted from comments by Israeli officials and by members of the OECD Economic and Development Review Committee. Special thanks to Federico Giovannelli for excellent research and statistical assistance, and Alexandra Guerrero for editorial assistance and coordination (OECD Economics Department).
} 
periphery. More importantly, significant socio-economic differences exist between the majority of the population and Ultra-Orthodox and Arab-Israelis who often live in separate towns, villages or neighbourhoods.

The benefits of the dynamic high-tech sector are concentrated in the centre of the country. More than $60 \%$ of all high-tech jobs are located in Tel Aviv and the central district, and approximately $80 \%$ of high-tech companies operate in this area. This trend has intensified in recent years, with the growth in high-tech employment in Tel Aviv constituting approximately $70 \%$ of the total national increase in this sector (Innovation Authority, 2018). As in other countries, the high-tech sector is concentrated, but its future growth will be constrained if it fails to fully utilise the periphery's human capital potential. The shortage of skilled high-tech workers is increasing, with an estimated 15000 unfilled jobs in the high-tech industry (Innovation Authority, 2018). This suggests that skills, transport or housing barriers exist that prevent people in peripheral locations from accessing the economically dynamic centre of the country. As Israel's territory is small, it needs to make the best use of all available resources and skills in order to remain globally competitive.

Figure 1. Income disparities among localities are high
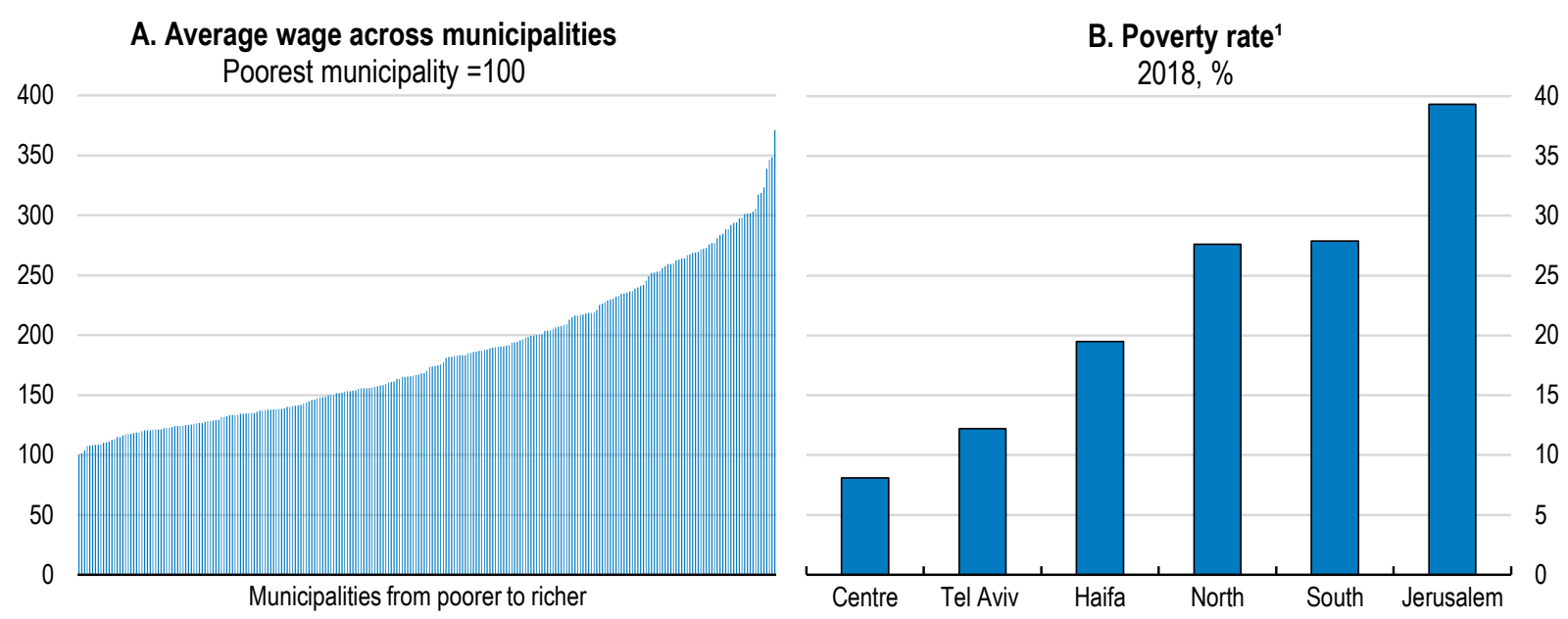

C. Gini coefficient ${ }^{2}$

Coefficient of variation, 2014 or latest year available

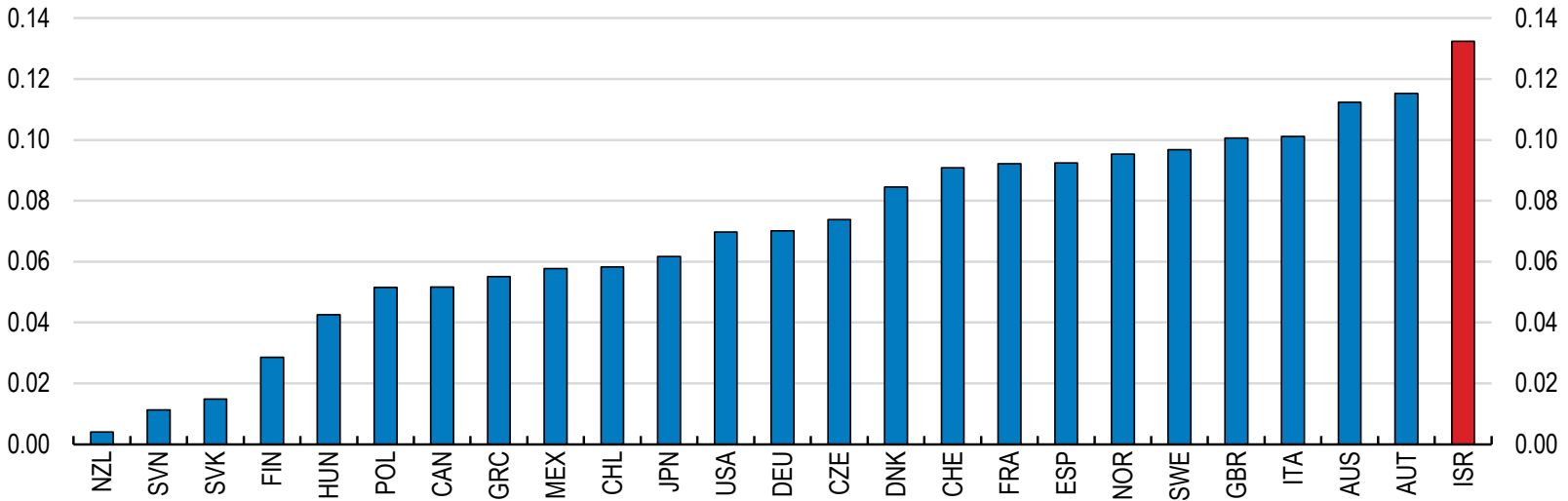

1. At-risk-of-poverty rate is defined as the share of people with an equivalised disposable income below the risk-of-poverty threshold, which is set at $50 \%$ of the national median equivalised disposable income.

2. The Gini coefficient is calculated for household disposable income after taxes and transfers, adjusted for differences in household size. The coefficient of variation is defined as the ratio of the standard deviation to the mean.

Source: National Insurance Institute (2019), Poverty and social gaps Report 2018, Table 12; Eurostat; OECD Regional Well-being database.

StatLink त्ञाIs https://doi.org/10.1787/888934152875 


\section{Figure 2. Disparities in disposable income have been widening}

Difference in per capita disposable income growth rate between the top and bottom $10 \%$ of large regions (2006-16)

$\%$ Average annual growth

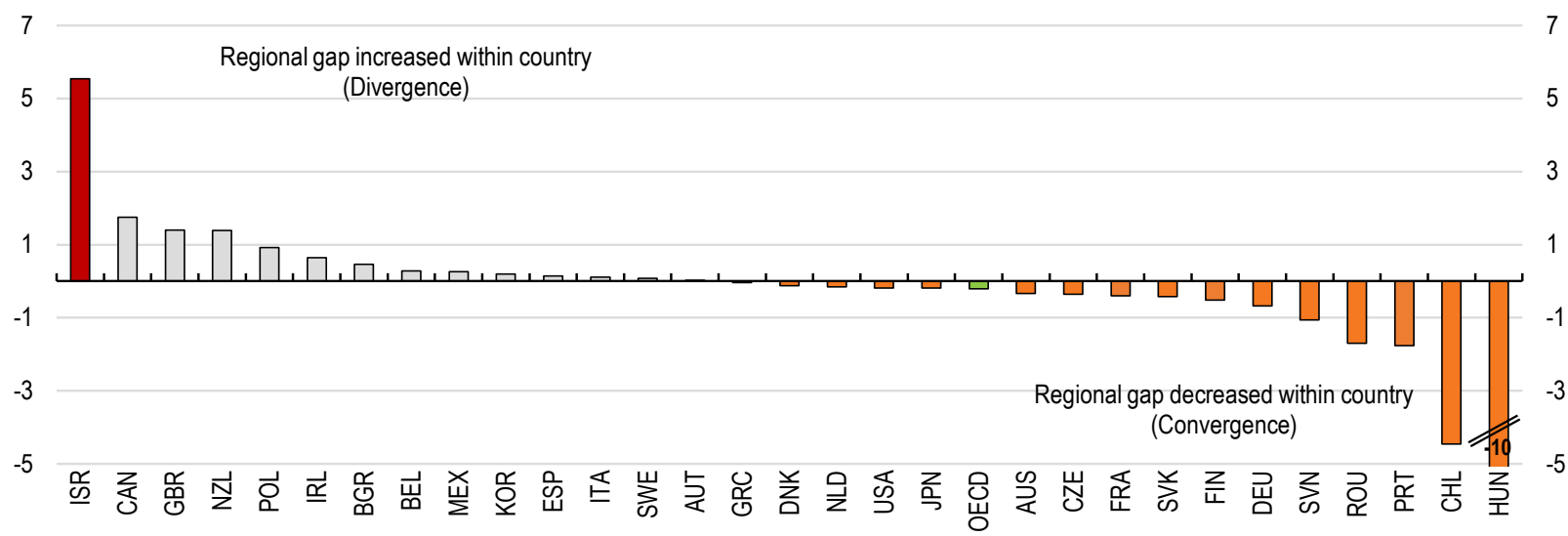

Note: The figure shows the change between 2006 and 2016 in the ratio of average disposable income per capita of the richest 10\% and poorest $10 \%$ TL2 regions. Richest and poorest regions are the aggregation of regions with the highest and lowest income per capita and representing $10 \%$ of national population.

Last available year: 2016; Canada, Finland, France, France, France, Germany, Hungary, Ireland, Japan, Mexico, New Zealand, Norway, Poland, Portugal, Slovenia, Spain and Turkey, 2016; Belgium and Switzerland, 2014; Italy and Sweden, 2013; Chile 2012.

First available year: Chile, Ireland, Israel, and Slovak Republic 1996; United Kingdom 1997; New Zealand 1998; Slovenia 1999; Austria, Denmark, Finland, Hungary, Portugal, and Sweden 2000; Japan 2001; Estonia and Mexico 2008; Korea and Poland 2010; Norway 2011.

Source: OECD (2018), OECD Regional Statistics database, http://dx.doi.org/10.1787/region-data-en

StatLink त्ञाज https://doi.org/10.1787/888934152894

Moreover, ethnic and religious groups with weak socio-economic status are concentrated in separate cities or neighbourhoods, which hampers their integration and mobility. Municipalities are usually divided along community, ethnic and religious lines. Spatial concentration of different communities is also common in other OECD countries but typically has less economic significance than in Israel. Segregation can represent a problem if it implies that disadvantages are spatially concentrated in cities and neighbourhoods with low job accessibility or a poor social environment. Highly segregated cities can lead to worse outcomes for individuals who start from a more disadvantaged situation (Sharkey, 2008; Sampson and Sharkey, 2008). Particularly, Arab-Israelis are primarily located in poorer areas, while Jewish residents are concentrated in wealthier municipalities (Figure 3). Arab-Israelis and Haredi living in mixed cities or in more diverse localities have better labour market outcomes than those living in segregated areas (Bol, 2016).

Arab citizens represent around $20 \%$ of Israel's population and live largely separated from the majority. Only one-tenth of the Arab population lives in mixed Jewish-Arab cities and the rest in separated cities, mostly in the north of the country and in the Negev district in the south (15\%). In these towns economic activity is generally weak and inward migration limited (Khamaisi, 2013). The Arabs living in Jewish localities and in mixed cities have much stronger socio-economic outcomes (Bol, 2016).

The Haredim represent one-tenth of the population, and the vast majority live in the centre of the country - the area bounded by greater Jerusalem, Bnei Brak (near Tel Aviv) and Ashdod. A large part of the Haredi population lives in predominantly Haredi neighbourhoods with their own schools and little day-today contact with other parts of the Israeli population (Machlica, 2020). Moreover, their share of the population is expected to increase to almost one-third by 2065 because of their high birth rates. The segregation of the Ultra-Orthodox has increased in recent decades due to rapid expansion of new UltraOrthodox cities fuelled by the significant increase in their population. The socio-economic outcomes for residents of Ultra-Orthodox cities, including labour market participation and household income, are much weaker than those of other Israelis. In contrast, Haredi residents of more diverse localities in the centre of the country have high employment rates and incomes compared to the average Haredim in Israel, and a tendency to work outside the Ultra-Orthodox community (Bol, 2016). 
Figure 3. Arab-Israeli and Haredi cities are much poorer
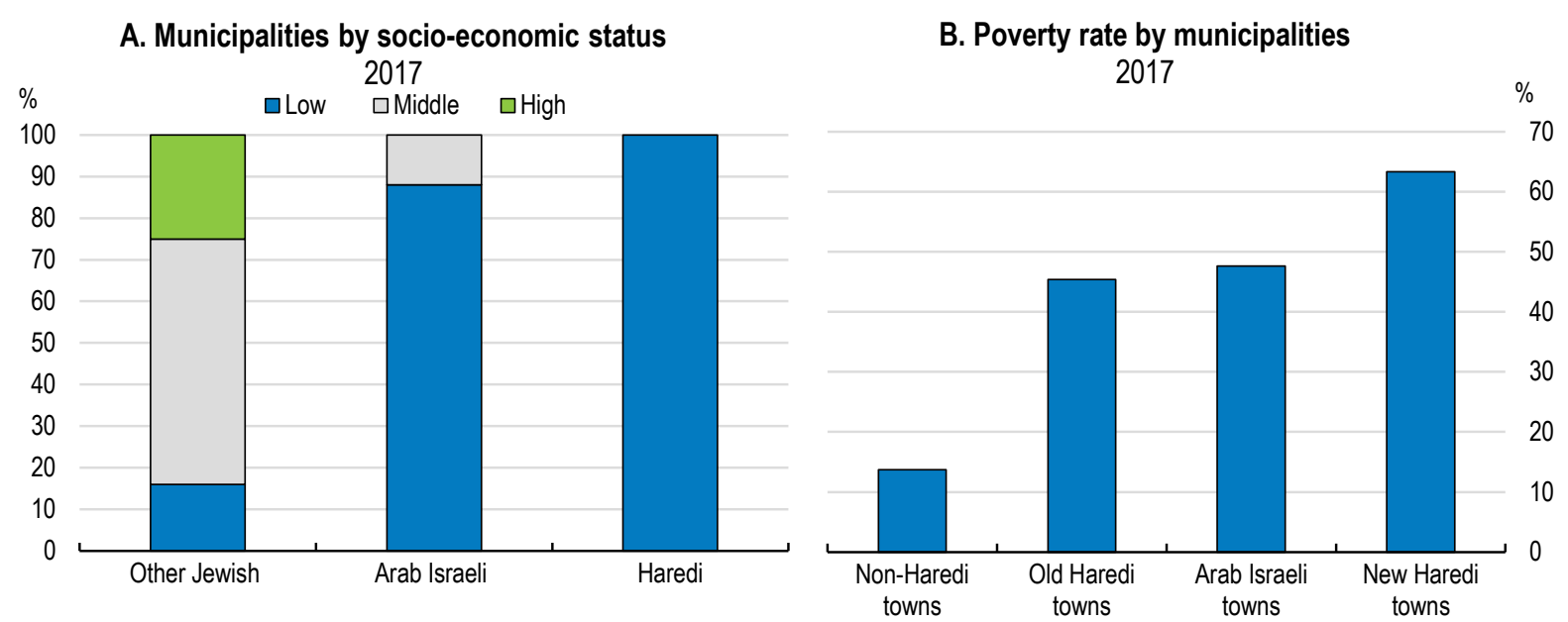

Source: J. Gal, S.Madhala and H. Bleich (2017):, "Social service budgeting in local authorities", Taub Center, A chapter from The State of the Nation Report 2017.

StatLink त्ञाज https://doi.org/10.1787/888934152913

Significant differences between areas in Israel also suggest that individuals' future socio-economic outcomes can be to some extent predicted by place of birth. Being born in a disadvantaged area can hamper social mobility across generations, especially for poorer households. Empirical research confirms that those born in poorer families in the periphery have fewer chances to improve their income relative to their parents' than poor children in the centre, and children from poorer households born in Arab-Israeli or Haredi municipalities also have fewer chances to improve their income compared to poor children in other municipalities (Krill and Bats, 2019). Lack of upward mobility at the bottom of the income distribution means that many potential talents are overlooked or under-developed (OECD, 2018b).

Therefore, Israel badly needs more inclusive growth to facilitate regional convergence so that everybody has an equal chance to succeed regardless of birthplace. The multi-dimensional nature of inequalities calls for a policy response that cuts across policy lines and levels of government and builds upon the strength and assets in peripheral areas. The government should put policies in place that give everyone the chance to succeed and reduce the barriers that prevent segments of the population from fully participating in the economy and in material progress. This will require: (i) access to public transportation; (ii) affordable housing and improved urban planning; and (iii) high-quality education in every municipality, which will help reduce spatial divides and segregation of disadvantaged households.

In particular, measurers to contain the COVID-19 should continue to be adapted to the needs of different cities. Experience from other countries and from Israel show that cultural minority groups can be particularly exposed to COVID-19 infection due to the interaction of various socio-economic vulnerabilities (Box 1). This requires measures first to respond to their needs and then also to mitigate the spread of the virus. 


\section{Box 1. Coronavirus infection rates across Israeli municipalities}

In OECD countries, the regional and local impact of the coronavirus outbreak has been highly asymmetric in the first phase of the outbreak. In China, $83 \%$ of confirmed cases were concentrated in Hubei province, in Italy, the country's north was hardest hit, in France, the regions of Île-de-France and Grand Est were the most affected as of 1 April (OECD, 2020a). Evidence from other countries also suggest that the outbreak disproportionally affected neighbourhoods with lower average incomes and larger families (Borjas, 2020).

The impact of the first phase of the outbreak has also varied substantially across Israeli municipalities. The infection rate has been particularly high in Haredi towns and neighbourhoods, while the infection rate in other Jewish neighbourhoods and Arab municipalities has been smaller (Figure 4). High infection rates can be related to large family size, crowded living conditions, intense social and community life, higher dependency on public transportation and higher share of low-skilled occupations with limited possibilities of teleworking. Empirical research suggest that the fraction of the population living in religious yeshivas or boarding schools and population density are the main explanations for the differences in infection rates between municipalities (Shores, 2020).

\section{Figure 4. Haredi towns have been particularly hit by the pandemic \\ Confirmed infection rate per 100000 (6th of August)}

3000

2500

\section{Improving transport infrastructure to spur growth in lagging municipalities}

Connecting disadvantaged groups to job opportunities and public services through effective transportation networks can reduce socio-economic differences and foster inclusive growth. Moreover, if Israel wants to remain a key player in high tech, it needs to compete with other larger metropolitan areas, which can use their agglomeration advantage. Given that Israel's area is small, it is important to set up a highly interlinked network of cities. For example, in the Netherlands there has been a great deal of focus on networking among cities trying to compensate for their small size with good connections to make more use of agglomeration benefits and of the periphery's human capital potential (Burger et al., 2013; Meijers et al., 2017). 
Israel's transportation infrastructure is under-developed. The core infrastructure stock is smaller by almost one third than those of other OECD countries (Figure 5). Investment activity in recent years has not been sufficient to meet the growing demand for transportation infrastructure. Over the past two decades the economy has been growing at a robust pace, with strong employment growth. As a result, the motorisation rate in Israel has increased by more than $50 \%$, from approximately 210 vehicles per 1000 inhabitants in 1998 to 320 in 2017 (Bol, 2019). The number of people working outside their residential locality has doubled in this period (Bol, 2017). In contrast, investment in road infrastructure and public transport as a share of GDP has remained relatively stable over this period, although it has increased most recently (Figure 6, Panel A). Commuting times have been steadily increasing. The average time required to travel to work outside the residential locality has risen significantly since 2005 (Panel B).

\section{Figure 5. Israel's current core infrastructure stock lags significantly behind other countries'} Total core infrastructure stock, 2015 (percent of GDP).

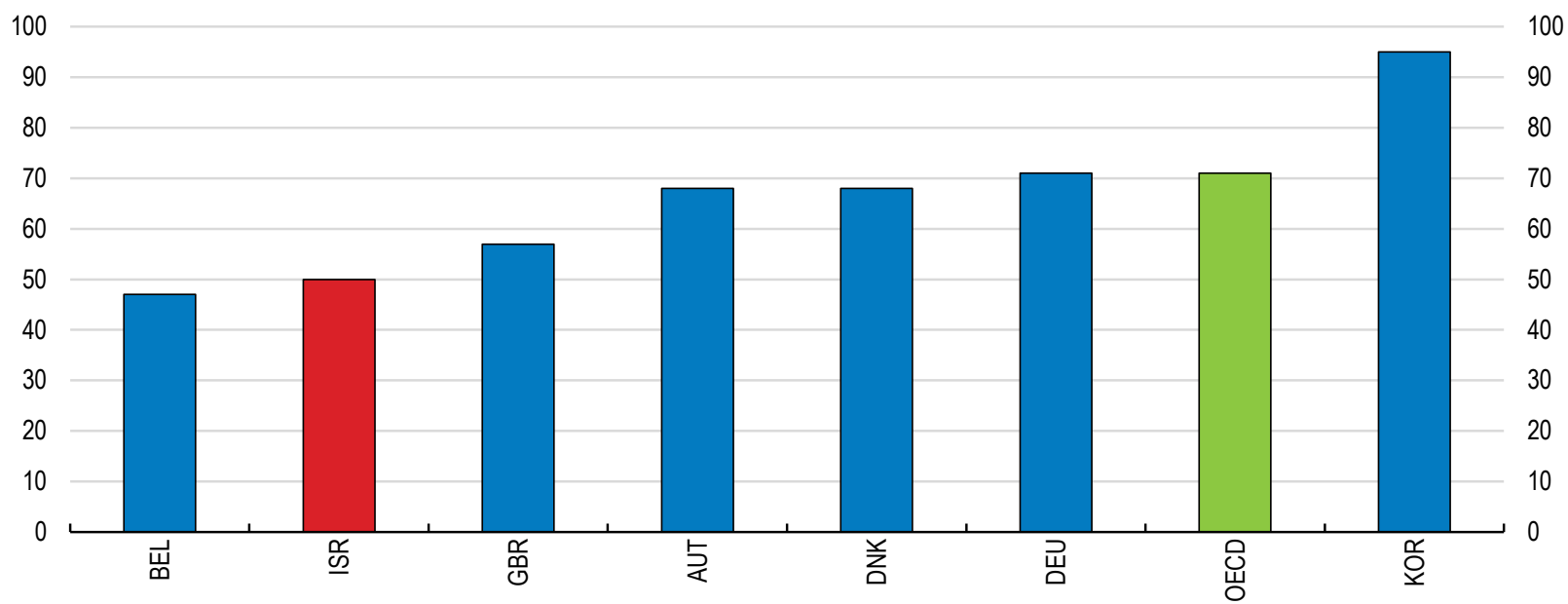

Source: Office of the Accountant General, Ministry of Finance; ITF; GWI; IHS Global Insight; McKinsey Global Institute analysis; Israel Rail; Israel Airport Authority.

StatLink 제표 https://doi.org/10.1787/888934152951

Figure 6. The supply of transport infrastructure has not been sufficient to meet rising demand

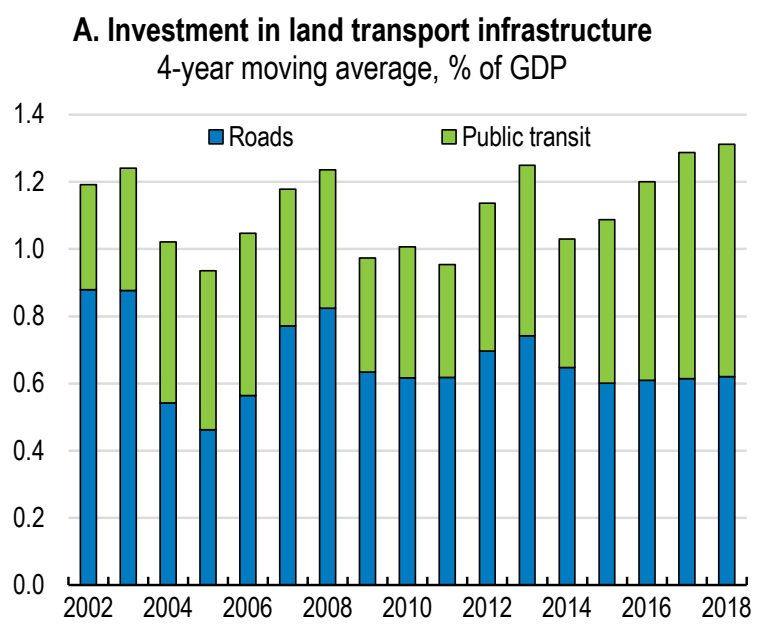

B. Duration of travel to work in Israel $2005=100$

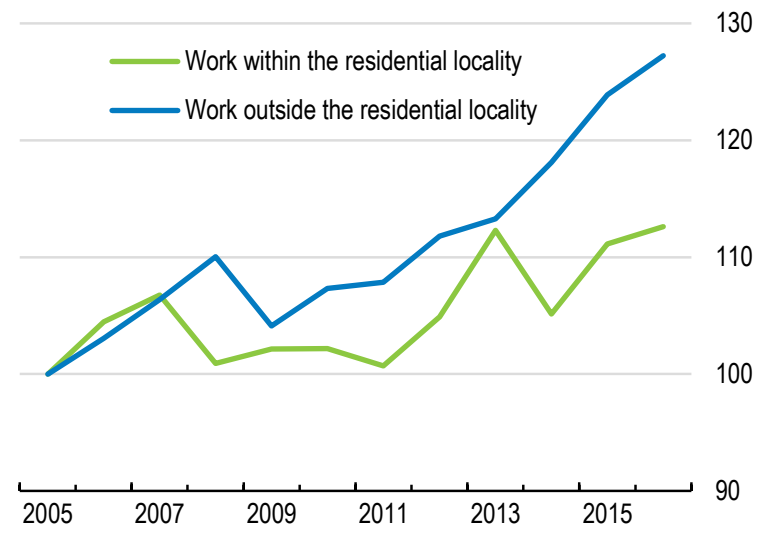

Source: Israel Central Bureau of Statistics 
Public transportation is crucial to connect disadvantaged groups to economic centres, but in Israel it is not only inadequate but also inefficient. The majority of public transport is provided through bus service, which needs much less investment than subway or light-rail infrastructure, but given insufficient investment in road infrastructure bus transport adds to congestion. The total distance travelled by an average Israeli in public transportation in metropolitan areas is about half of that in other developed countries (TSC, 2019).

Furthermore, limited availability and the low quality of public transit hinder accessibility to better paying jobs for poor households with low levels of motorisation. Many Israelis use public transit as a last resort when they do not have a private vehicle available (Bol, 2017). Less than $10 \%$ consider public transport efficient, and satisfaction with public transit in the three largest cities in Israel is much lower than in the major cities of Europe (Suhoy and Sofer, 2019; Bol, 2017). The main complaints are that buses are not sufficiently frequent and are too slow (TSC, 2019). The average speed of public transportation in Israeli cities is only $16 \mathrm{~km} / \mathrm{h}$, compared to $25 \mathrm{~km} / \mathrm{h}$ in the average OECD country (TSC, 2019). Moreover, there are large differences in terms of access to public transit services between municipalities that are mainly inhabited by non-Haredi Jews and others (TSC, 2019). Access to public transit is lowest in small and peripheral urban centres and majority-Arab towns (Figure 7).

\section{Figure 7. The accessibility to public transit is weak, particularly in peripheral areas}

Towns and localities according to accessibility to public transport

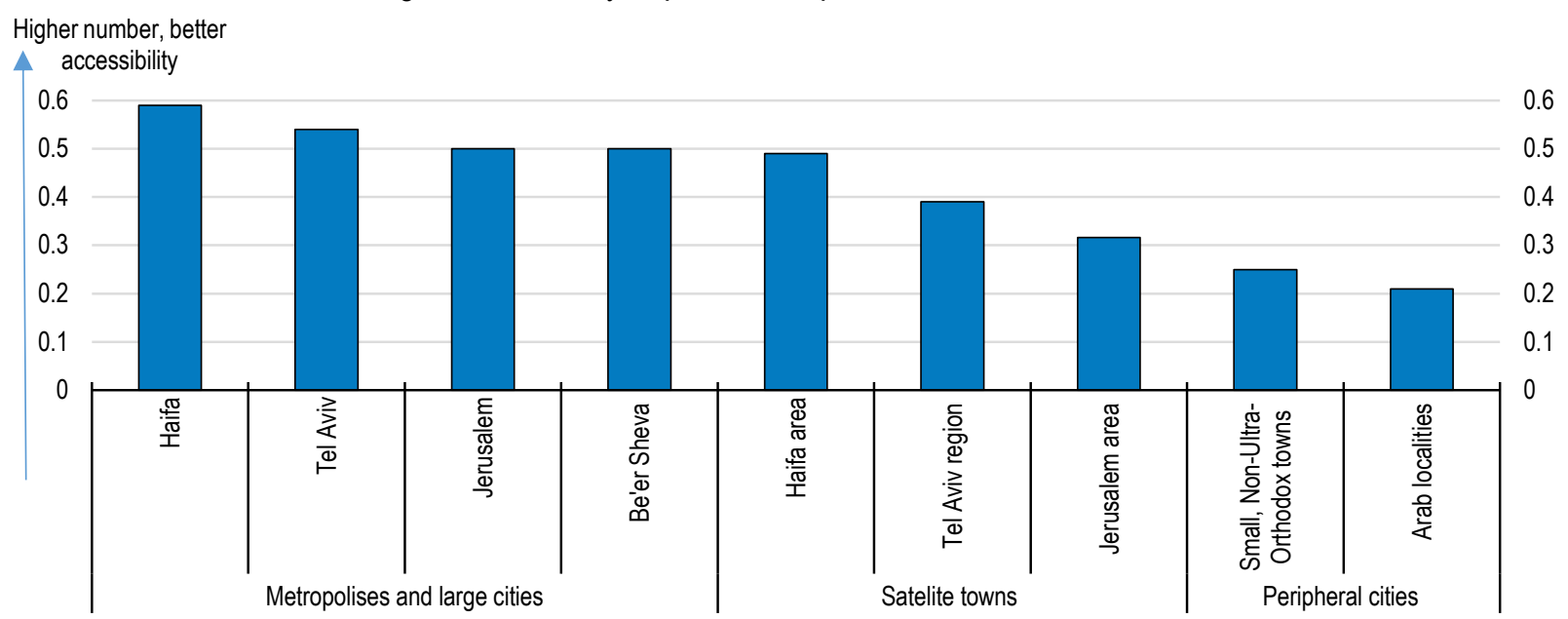

Source: T. Suhoy and Y.Sofer (2019) "Getting to Work in Israel: Locality and Individual Effects", Bank of Israel, Research Department, https://www.boi.org.il/he/Research/DocLib/dp201902h.pdf

StatLink त्गा5 https://doi.org/10.1787/888934152989

\section{The transport infrastructure and public transport network need to expand}

The government is aware of the unsatisfactory situation and has outlined several strategic plans to close the large infrastructure gaps over the coming decades. Investment in public transit has increased in recent years due to large-scale infrastructure projects, such as the Tel Aviv-Jerusalem rail line and the red line of the Tel Aviv light rail; but it remains low (Bol, 2017). These investments to finance transport infrastructure and public transport are necessary, but the expenditures should not be allowed to erode public finances, and, as was suggested in the previous Economic Survey (OECD, 2018c), some infrastructure projects can be financed through public-private partnerships (PPPs). PPPs have helped reduce the costs of new electricity production facilities based on renewable resources and assisted with the construction of very energy-efficient desalination capacity in the water sector (OECD, 2018c). However, they still entail risks for public finances in the form of contingent public liabilities. Therefore, it is important that the management procedures for PPPs be aligned closely with best practices based on international and domestic experience. Quantitative assessments comparing the value for money offered by PPPs relative to 
alternative procurement routes should be made public, in line with the OECD Principles for Public Governance of PPPs (Pisu et al, 2015; OECD, 2014a). Also, entrusting supervision and management of these contracts to a single public agency would be advisable (OECD, 2018c). The Ministry of Finance should closely monitor contingent liabilities.

Introduction of congestion charges can represent an additional source of public transport funding. This would not only help provide resources for the underlying capital investment but would also help reduce congestion and improve air quality and public health. In Israel, most levies and taxes related to road transit have no direct link with the use of infrastructure, which leads to over-utilisation of existing capacity. Road traffic intensity, in terms of vehicle-kilometres driven per kilometre of road network, is much higher than in other OECD countries (Figure 8). Congestion causes real damage to the economy and quality of the life of residents, due to the loss of both work and leisure hours and the increase in air pollution and in road accidents.

Congestion charges are generally considered to be an effective traffic regulation system. Several other OECD countries have introduced such charges. For example, London introduced its congestion charges, while improving public transport at the same time. Transport quality has improved, and 300 new buses were put into service in order to increase frequency (OECD, 2019a). In Milan revenues from congestion charges fund public transport improvements including higher bus frequency, long-term measures such as extensions of the subway network and other changes to promote sustainable mobility services (OECD, 2019a).

Israeli congestion is worst in the metropolitan area around Tel Aviv, where around $60 \%$ of the countrywide congestion costs are estimated to occur. Indeed, Tel Aviv is the fourth most congested city in the OECD (TomTom, 2019). This calls for focusing congestion charging on Tel Aviv and, possibly, Jerusalem. Nationwide congestion charges are less common across OECD countries. Israel should consider the adoption of GPS-based monitoring technologies, which are likely to substantially increase efficiency by adding a large degree of pricing flexibility (OECD, 2019a).

A complementary approach to congestion charges is to improve the efficiency of parking policies. Parking fees in Israel in cities are very low or zero for many car users. However, experience from other countries shows that free or under-priced parking increases the costs of parking supply and land use, implying that funds that could possibly be directed to improve the public transport system are used for parking (Russo et al., 2019). Therefore, congestion charges need to be combined with increased parking charges in central areas. For example, Singapore constantly improves and expands its current public transport network, complementing it with electronic road pricing and parking policies, resulting in a shift from private to public transport in recent years (Aguilar Jaber and Glocker, 2015). 
Figure 8. Traffic intensity is significant in Israel

Road traffic intensity per network length, 1000 vehicle-km driven/km, 2014 or latest year available

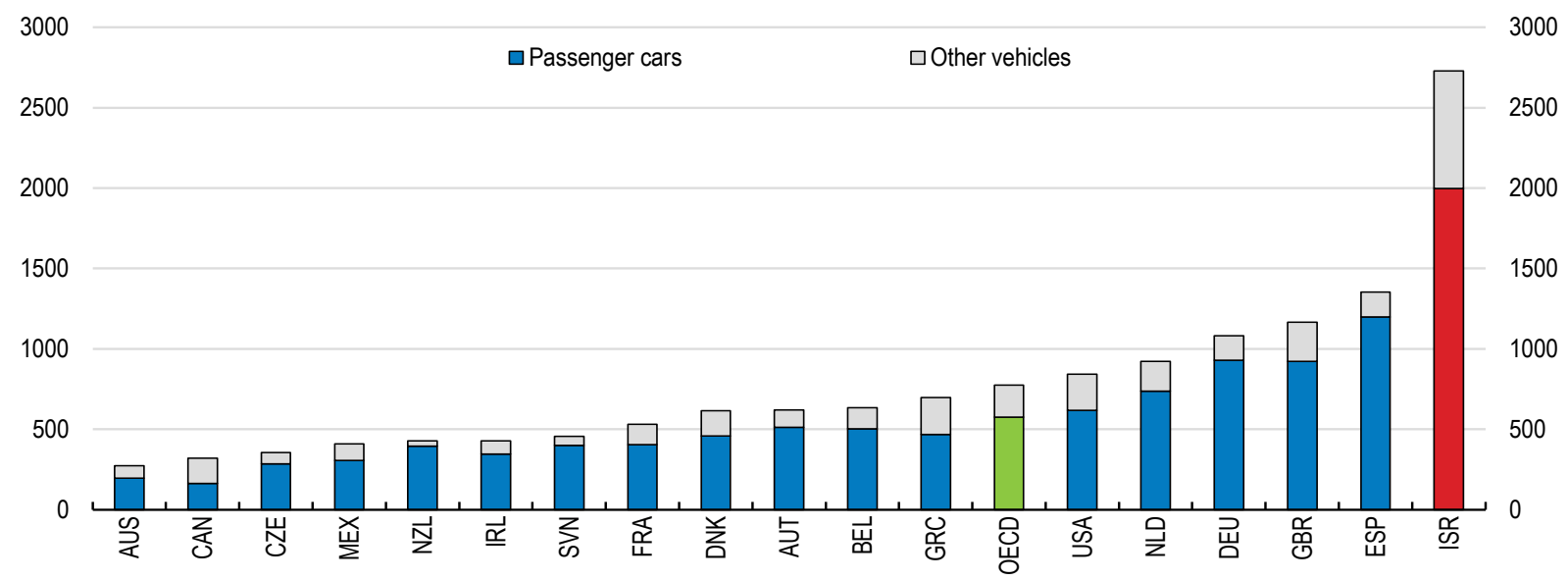

Source: OECD (2015), Environment at a Glance 2015: OECD Indicators, OECD Publishing, Paris.

StatLink :्गाड़ https://doi.org/10.1787/888934153008

\section{Enhance the effectiveness of infrastructure governance}

Israel's infrastructure project management capacity is weak compared to other countries (Hertie School of Governance, 2016). Improving governance and regulation to the level of the best OECD performers could bring sizable productivity gains (Demmou and Franco, 2020). As the previous Economic Survey suggested, transparency and long-term strategic planning should be enhanced by introducing systematic cost-benefit analyses entrusted to an independent agency that would also publish its results (OECD, 2018c). It is of the utmost importance that regional perspectives are taken into account, giving priority to projects that improve connectivity among regions.

Another problem is that the existing division of responsibilities between the central government and local authorities hinders infrastructure project development. The coordination in infrastructure governance across levels of governments is one of the weakest in the OECD (Hertie School of Governance, 2016). Large projects require the consent of local authorities in the jurisdictions where the project takes place. This often leads to lengthy negotiations that hinder the advancement of projects, especially since the local authorities are focussed on their own local needs. For example, the planning of a fourth railway track along the Ayalon Highway took nearly 10 years to finish (Globes, 2019). The currently planned building of a Tel Aviv metro, a mass transit subway system connecting many cities in central Israel, has faced many disputes from local authorities at the planning stage, which risk delaying the start of construction for many years. Therefore, co-ordination is necessary to identify investment opportunities and bottlenecks and to ensure adequate resources and capacity to undertake investment (OECD, 2014a).

One way forward is the establishment of metropolitan transit authorities (MTAs). Several attempts to establish metropolitan authorities in Israel have failed (TSC, 2019). However, their establishment could help to promote transit solutions in line with national and local needs. MTAs would have the capacity to better understand commuting patterns and transit needs across the wider economic area and help to better prioritise investment, facilitate decision-making regarding regional linkages and promote coordination and common pricing systems that make public transport more attractive. Experience from other OECD countries shows that better integration of transit management in metropolitan areas can contribute significantly to higher growth and well-being (OECD, 2015). Rotterdam, Barcelona, London and Paris have established some of the world's most effective metropolitan transit authorities (OECD, 2016a; ITF, 2018; Box 2). 


\section{Box 2. Metropolitan transport authorities in selected countries}

London, Paris and Barcelona have introduced MTAs as they faced common challenges, including the lack of an integrated transport network, overlapping responsibilities regarding the various transport modes and inefficient mechanisms to ensure stable financial support for public transport.

MTAs' responsibilities related to transport governance in these cities are:

(i) operational responsibilities, including the setting and collection of fares; and

(ii) strategic and planning responsibilities, including strategy, policy and infrastructure planning and funding of major infrastructure projects.

A common feature among these cities' MTAs is that all of them carry out strategic planning and have a high level of control over planning of public transport infrastructure and services (Table 1).

Table 1. Responsibilities of MTAs (high, partial, no responsibility)

\begin{tabular}{|c|c|c|c|c|c|c|c|}
\hline \multirow[t]{2}{*}{ City } & \multirow[t]{2}{*}{ MTA } & \multirow{2}{*}{$\begin{array}{l}\text { Strategic } \\
\text { planning }\end{array}$} & \multicolumn{3}{|c|}{ Public transport } & \multirow{2}{*}{$\begin{array}{c}\text { Traffic } \\
\text { management and } \\
\text { parking policies }\end{array}$} & \multirow{2}{*}{$\begin{array}{l}\text { Road } \\
\text { safety }\end{array}$} \\
\hline & & & $\begin{array}{l}\text { Planning infrastructure } \\
\text { and services }\end{array}$ & $\begin{array}{l}\text { Fare } \\
\text { setting }\end{array}$ & Investment & & \\
\hline London & TfL & high & high & high & high & high & high \\
\hline Paris & ÎFM & high & high & high & high & no & partial \\
\hline \multirow[t]{2}{*}{ Barcelona } & ATM & high & high & high & no & no & no \\
\hline & AMD & high & high & no & high & high & no \\
\hline
\end{tabular}

\section{Financing of the MTAs in Paris, London and Barcelona}

Île-de-France Mobilités in Paris is $50 \%$ financed by the transport tax, which is paid by companies with more than nine employees that are located in proximity to the transport network; the tax is paid as a percentage of the employer's total payroll cost. Additional income comes from fares, including driving and parking fines $(30 \%)$. The rest of the MTA's budget $(20 \%)$ is from regional, department and municipal authorities.

Transport for London (TfL) is financed through fares ( $47 \%$ of the budget), grants and funding for Crossrail $(23 \%)$ borrowing $(17 \%)$, and other sources $(13 \%)$ including revenue from congestion charges and commercial development of the MTA estate.

Barcelona has two-level arrangement: ATM (Autoritat del Transport Metropolità) is established for the wider commuting zone and AMB (Área Metropolitana de Barcelona) serving the urban core. ATM's budget comes from two main sources: government grants $(53 \%)$ and fare revenue $(47 \%)$. AMB's budget has four main sources. Municipalities across AMB pay a "metropolitan tax", a specific tax charged to all municipalities within the AMB ( $15 \%$ of the budget), surcharges such as waste management municipal taxes from municipalities $(25 \%)$ and regular fares $(52 \%) ; 5 \%$ is from charges for concessions on private operators, including Aerobus and tourist buses

The text in this box is based on information from: F. Lloveras Minguell (2018), "Public Transport Governance in Greater Barcelona", Discussion Paper, International Transport Forum, Paris; and ITF (2018), " Policy Directions for Establishing a Metropolitan Transport Authority for Korea's Capital Region", International Transport Forum Policy Papers, No. 61, OECD Publishing, Paris.

Establishing a metropolitan transport authority entails transferring some of the responsibilities and funding assigned to lower levels of local government to the new metropolitan institution. An appropriate budget is crucial to delivering benefits and to ensuring that the MTA is a durable institution. In Israel, congestion charges and fares should be the main sources of financing; other possibilities include surcharges such as municipal waste management taxes.

There is also room for more competition to improve the quality of public transit. Israel's product market regulation in infrastructure is currently stricter than other countries' (Figure 9). Bus service regulations were reformed in 2000 and 2014 . These included opening the market to competing bus lines, which were 
previously controlled by two monopolies. After the reforms, 11 new operators started competing to provide regular bus service. Market competition has led to price reductions, higher passenger numbers and better quality (Ida and Talit, 2017a). However, there are still several barriers to competition in this area: access is open in only half of the total market for bus services, with the remaining half still controlled by the two monopolies. Comparing the competitive and monopoly-run bus services reveals significant differences, highlighting the advantages of the competition-based approach, including higher numbers of passengers and cheaper fares (Ida and Talit, 2017b).

\section{Figure 9. Transport regulation is heavy in Israel}

Product market regulation indicator from 1 (least restrictive) to 6 (most restrictive), 2018

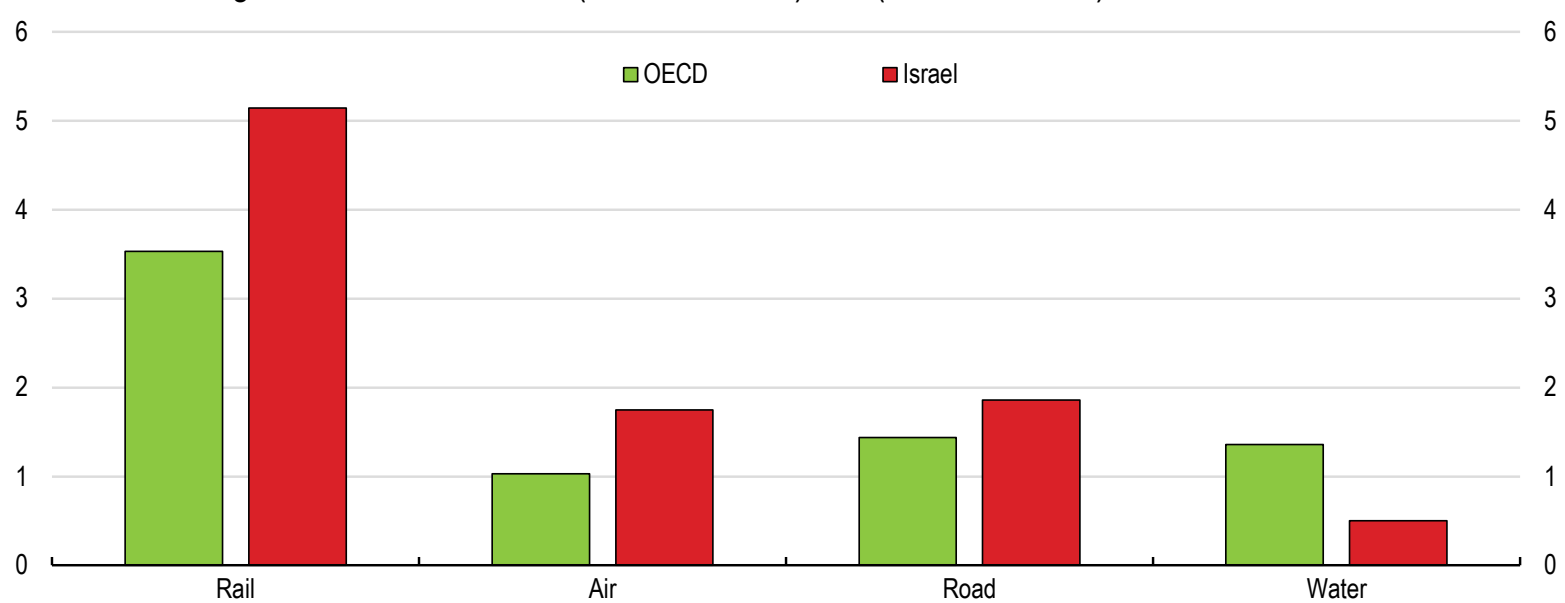

Source: OECD Product Market Regulation Indicators.

While improving public transport and related infrastructure can be a powerful tool to boost accessibility to employment opportunities for disadvantaged groups, it should be accompanied by other measures. Empirical research has shown that high-quality public transport can help to overcome the effects of distance from suitable employment opportunities, particularly for low-skilled workers who are not able to afford cars (Tyndall, 2017). However, the effect on disadvantaged groups can be limited (Barak, 2019) if is it not accompanied by a more holistic policy approach, including education or housing policies. Therefore, in order to significantly increase employment rates among the Arab or Haredi population, other barriers such as skills gaps and the lack of housing must be addressed simultaneously.

\section{Improving the economic policy framework for the housing market}

Another way to connect disadvantaged groups to job opportunities is to promote affordable housing near Israel's economic centres. Access to good-quality, affordable housing is essential to enhance equality of opportunity, social inclusion and mobility. This is particularly important for Israel, which faces a housing deficit fuelled by rapid population growth (OECD, 2017a). The undersupply of available housing led to significant price increases, over 70\% in real terms between 2007 and 2016. Prices have stabilised recently but remain high in international comparison (OECD, 2018c).

Rapid increases in housing prices have exacerbated inequalities and widened regional differences. Poorer families cannot afford to own an apartment, and the rent burden is high in international comparison, particularly for low-income tenants (Figure 10). Limited housing and increasing prices have forced lowerincome households to relocate to more affordable areas with fewer economic opportunities. Indeed, house prices are strongly affected by their proximity to metropolitan centres: the price of housing in Israel declines 
with the distance from Tel Aviv to the same extent in all directions (Eckstein et al., 2012). This can represent a barrier to better employment opportunities and income. Evidence from other OECD countries suggests that higher housing prices, which force workers to stay in less productive regions, can have a substantial negative impact on the economy (Hsieh and Moretti, 2015).

\section{Figure 10. Housing costs are high for poor households}

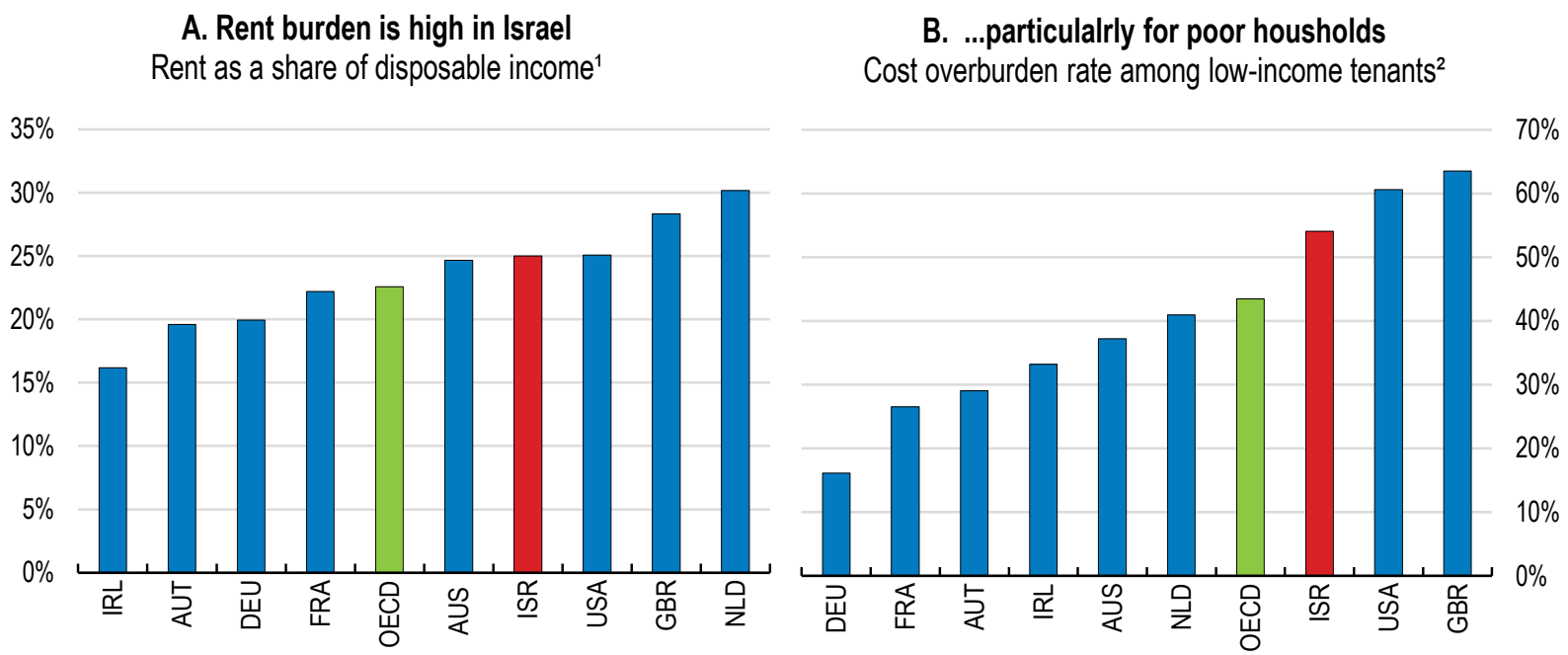

1. Median of the mortgage burden (principal repayment and interest payments) or rent burden (private market and subsidised rent) as a share of disposable income, in per cent, 2015 or latest year available.

2. Share of population in the bottom quintile of the income distribution spending more than $40 \%$ of disposable income on rent, in per cent, 2015 or latest year available.

Source: OECD calculations based on European Survey on Income and Living Conditions (EU SILC) 2015 except: from the Household, Income and Labour Dynamics Survey (HILDA) for Australia (2014); the German Socioeconomic Panel (GSOEP) for Germany (2014); American Community Survey (ACS) for the United States (2015) and Bank of Israel for Israel (2015).

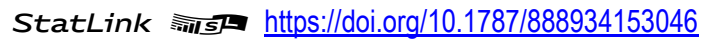

It is thus important to provide effective land-use and housing policies, which can have significant implications for wealth distribution and can improve local economic development (OECD, 2017b).

\section{Municipalities favour business development over residential growth}

Local authorities play a role in housing and land planning, as they influence the zoning of land use through their individual urban plans. However, Israeli municipalities do not prioritise residential development, despite the pressing need for more housing in the country.

The current property tax system creates incentives for them to favour business over residential development. Local property tax (Arnona) is the main source of municipal revenue, and business properties have much higher tax rates than residential properties. The property tax charged for commercial and industrial parks can be 11 times higher than that on residential properties (OECD, 2017a). The Israeli property tax is area-based and depends on the square metres of a given property. It reflects the property's size, location, age and use (commercial, residential, industrial, etc.). This is in contrast to many other OECD countries where the tax is based on the assessed value of the property (OECD, 2020b).

At the same time, municipalities with more residents have higher expenditures, as they need to provide more municipal services for these residents. Moreover, large-scale residential projects require major infrastructure components (OECD, 2017a). Therefore, having more residents represents a net loss for local authorities. They are thus incentivised to develop industrial parks and commercial centres at the expense of residential areas. As a result, the supply of land available for commercial-industrial parks exceeds the market demand, and in many cases this land remains largely empty (OECD, 2017a). 
Moreover, municipalities tend to prioritise attracting high-income earners in residential projects instead of poor young families or the elderly who are both intensive consumers of municipal services. These groups not only require higher spending but can receive tax breaks resulting in loss of revenues. Low-income families, the elderly and students are granted exemptions and discounts by the central government. Therefore, local governments tend to direct housing supply to more expensive and upscale housing and reduce the share of small apartments (OECD, 2017a). Indeed, the construction of larger apartments dominates the market. While in the 1980s the share of three-room apartments represented over one-third of all new dwellings, today they represent only around $10 \%$ (Figure 11).

\section{Figure 11. Newly built houses are increasingly tilted towards large-size and luxury housing}

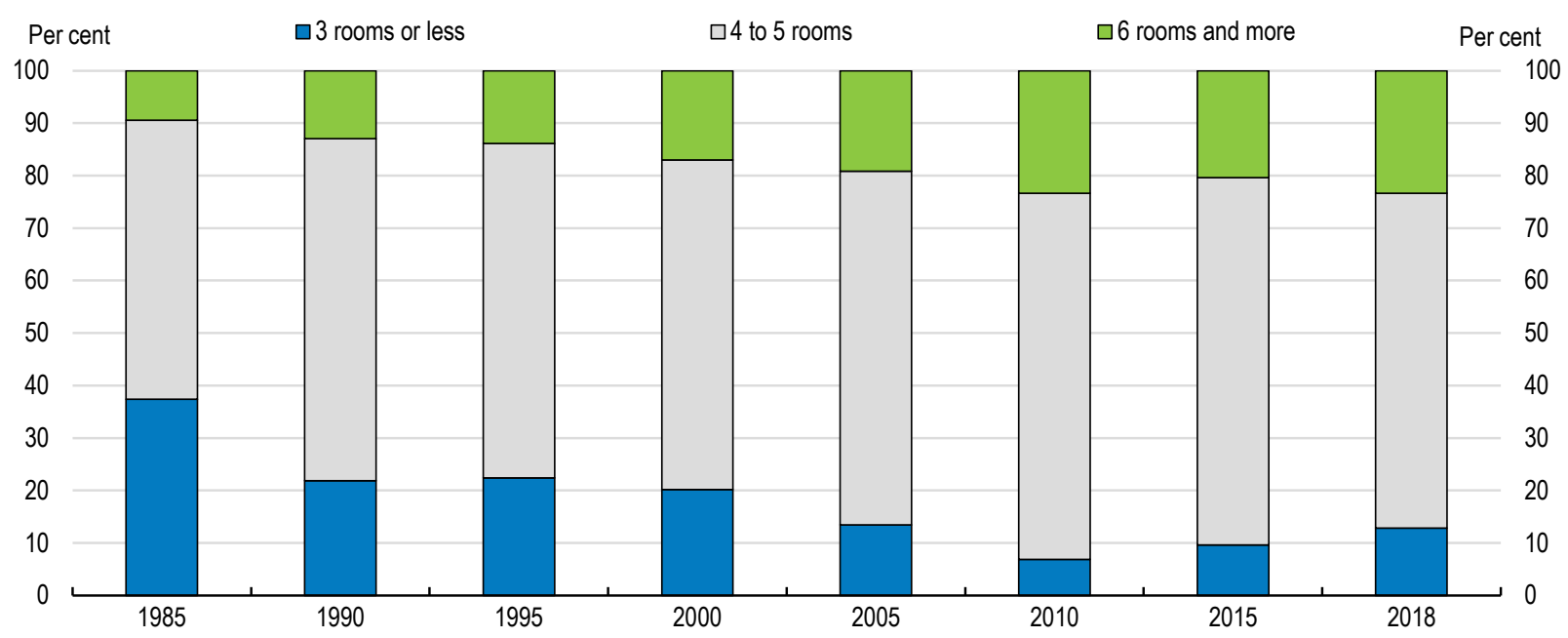

Source: Israel Central Bureau of Statistics

The government has taken several steps aimed at weakening the negative incentives facing local authorities regarding residential development. "Umbrella agreements", introduced in 2014, provide them with additional financing. According to these agreements the government finances the infrastructure and the public buildings required for new neighbourhoods, while the local authorities issue building permits and approvals for the building plans. The Umbrella agreements also allow local authorities to use the funds for the renewal of infrastructure in old neighbourhoods.

However, the Umbrella agreements provide funding only at the initial construction stage, but the new residents also require additional expenditures on education and social and other public services. Poorer municipalities will be put under fiscal pressure to provide additional services for new residents. The approved construction projects within the Umbrella agreements assume a significant population boost will take place in a number of municipalities. In a third of them, the population is expected to almost double (Figure 12). This will create heavy fiscal pressure on these municipalities, who will be challenged to absorb such a significant addition to their population without additional government support. Moreover, the Umbrella agreements have been signed primarily with financially weaker local authorities that already have trouble providing adequate services to their population (Bol, 2017). This represents a particular challenge for the municipalities with high population growth. Addressing this challenge will require changes to the municipal property tax system (see below) or changes to the planning process to take into account the financial strength of municipalities. 
Figure 12. Umbrella agreements assume significant population increase in poorer municipalities Municipalities under umbrella agreements according to expected population increase and fiscal strength

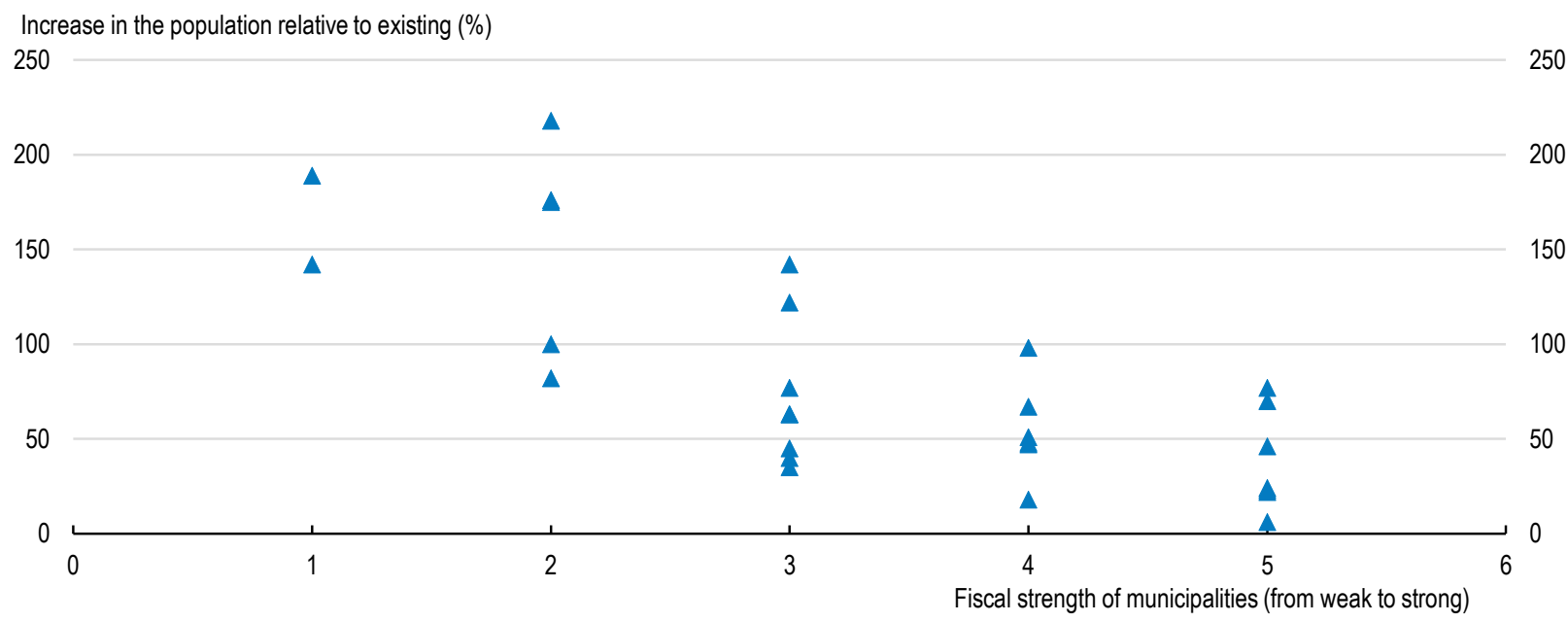

Source: Bank of Israel (2017), National Report.

StatLink त्ता SD https://doi.org/10.1787/888934153084

\section{More incentives for residential development should be provided}

The government needs to reduce the current differences between residential and non-residential tax rates. The current large differences in rates not only encourage municipalities to provide land for commercial use at the expense of residential housing but also contribute to sizeable differences in revenues between municipalities. To reduce this gap the non-residential property tax rates could be lowered and the residential rates raised. To offset possible regressive effects of higher residential property tax rates, the central government should standardise most residential Arnona discounts and exemptions for low-income households.

In this regard the government should establish a value-based system of property taxation for nonresidential and residential property (see ECO/WKP(2020)45). Value-based property tax systems perform better in terms of equity compared to the current area-based property tax (OECD, 2019a). This will require municipalities to have the capacity to estimate market values of properties on a systematic basis. Comparing selling prices is the most common method in OECD countries to assess property values: under this a property's value is determined by comparing the sales prices of other properties with similar characteristics (Blöchliger, 2015). In Israel, the market values of non-residential properties already exist in the form of the information that businesses must provide (OECD, 2020b).

The current property tax system is not the only reason for insufficient housing supply. In the medium to long term, land-use planning could be further decentralised and made more flexible. In recent years many OECD countries have shifted towards more flexibility within their planning systems in order to reduce the amount of time and effort needed to receive planning and building permissions (OECD, 2017b). However, more flexible land-use planning requires fulfilling a number of conditions. First, municipalities need stronger incentives to develop residential areas (see above). Second, they need to improve their capacity in terms of human resources, technical skills and use of modern IT systems. Capacity limitations limit the possibility for more flexible and decentralised land-use planning, which can help to improve efficiency of residential construction.

Before the 2014 reform the residential construction process took on average 13 years, with the actual construction accounting for two of those years, while the remaining 11 years were devoted to bureaucratic proceedings (Gruber, 2014). One of the reasons for this was that the six district-level planning committees were overburdened issuing building permits for many small-scale housing construction projects. The 2014 
reform devolved these approvals from the district level to 127 local planning committees, which helped speed up the process. In the future the government could consider allowing even more flexibility and further decentralisation, together with increasing the number of planning committees, which could improve efficiency, although this step should be conditional on available capacities within the planning committees. The local planning committees can more efficiently approve small-scale development projects and can help free up resources for the district-level committees to focus on large-scale housing projects (OECD, 2017a).

\section{More support should be provided to Arab-Israeli municipalities}

Assistance and support should be provided to local authorities facing significant housing challenges, particularly the Arab municipalities. The municipal jurisdictions in Arab cities are four times smaller than those in the rest of the country (Figure 13, Panel A), with only a small portion of public land. At the same time, Arab municipalities have less outward migration: only $2 \%$ of their residents move out annually. Residential building construction is slow (Panel B), as most Arab localities do not have their own planning and building committees and are therefore regulated by district planning committees. This is partly due to their lack of resources and local planning capabilities (OECD, 2017a).

\section{Figure 13. There is much less land per capita in Arab-Israeli municipalities}

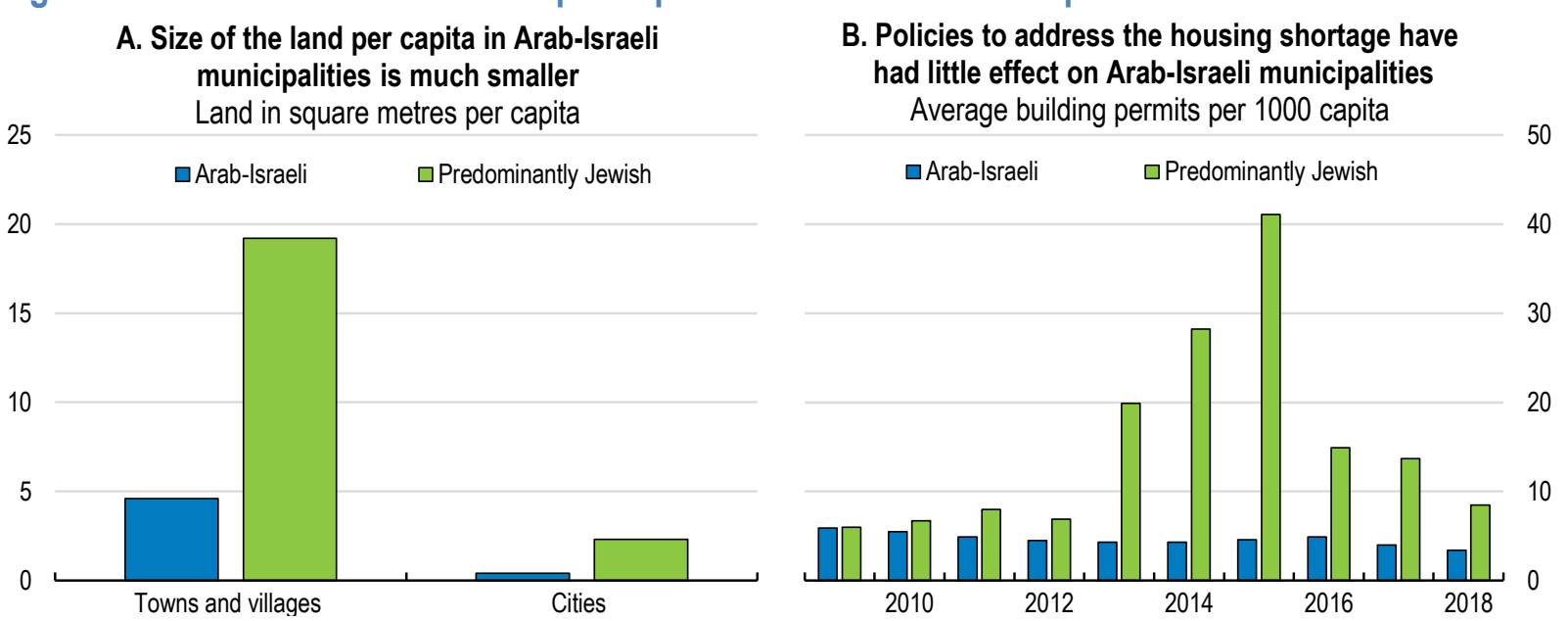

Note: A municipality is classified as Arab if over $50 \%$ of its population is Arab. Cities refers to municipalities that have at least 20000 residents, while towns and villages refer to all other municipalities.

Source: OECD calculation using Israel Central Bureau of Statistics data.

StatLink ज्ञाs https://doi.org/10.1787/888934153103

A major challenge is the lack of land registration. In many Arab municipalities landowners do not register their land due to a lack of trust in the government, a complicated registration process and tax avoidance, as land transactions involve various taxes such as land excise tax, capital gains tax and taxes on real estate transfers (OECD, 2017a). In some cases, the registration process can be costly due to legal work and land readjustment requirements if several landowners are involved. Moreover, many houses have been built without a permit.

Unregistered housing results in a delayed planning and construction process and can represent huge tax losses for the municipalities. These housing units lack basic infrastructure, do not adhere to safety regulations and face the risk of fines and even eviction. This problem is widespread across Arab municipalities (OECD, 2017a). Households living in homes built without a permit also lack access to loans, since the property cannot be used as collateral. 
Legalisation and formalisation of property rights will be crucial in Arab municipalities. The government has already taken steps in this direction and most of Arab municipalities have their valid building outline plans in the process of approval. The government should also step up efforts to reduce unregistered housing and ensure retroactive approval of housing units or grandfathering recognition of buildings that were built as a result of the lack of regulatory procedures in the past (OECD, 2017a). More highly trained municipal staff and closer interaction with central government are essential for improving the management of Arab municipalities, including by increasing their relatively low tax-collection rates and updating their plans for buildings on their territory (Belikoff and Agbaria, 2014).

\section{Expanding social housing in economic centres}

Another measure that can promote affordable housing is housing assistance. Israel furnishes housing assistance to poor households by either subsidising market rent or providing social housing. Rent subsidies partly cover rents in the private market. About $6 \%$ of households received such subsidies. While rent subsidies are prevalent in Israel, they are still low in international comparison (Bol, 2015).

The share of social housing is also relatively low (Figure 14), and the number of poor families in Israel exceeds the supply of public housing. The waiting list for public housing has increased by $50 \%$ since 2017 , reaching almost 4000 families. The supply of available public housing has decreased over the last decade as large numbers of these housing units have been sold to the tenants at discounts in order to reduce poverty and support private home ownership. In 2018 alone almost 1500 dwellings were sold at an average discount of 60 percent from the market price (Bol, 2018).

\section{Figure 14. Social rental housing is relatively small in Israel}

Per cent, 2015 or latest available year

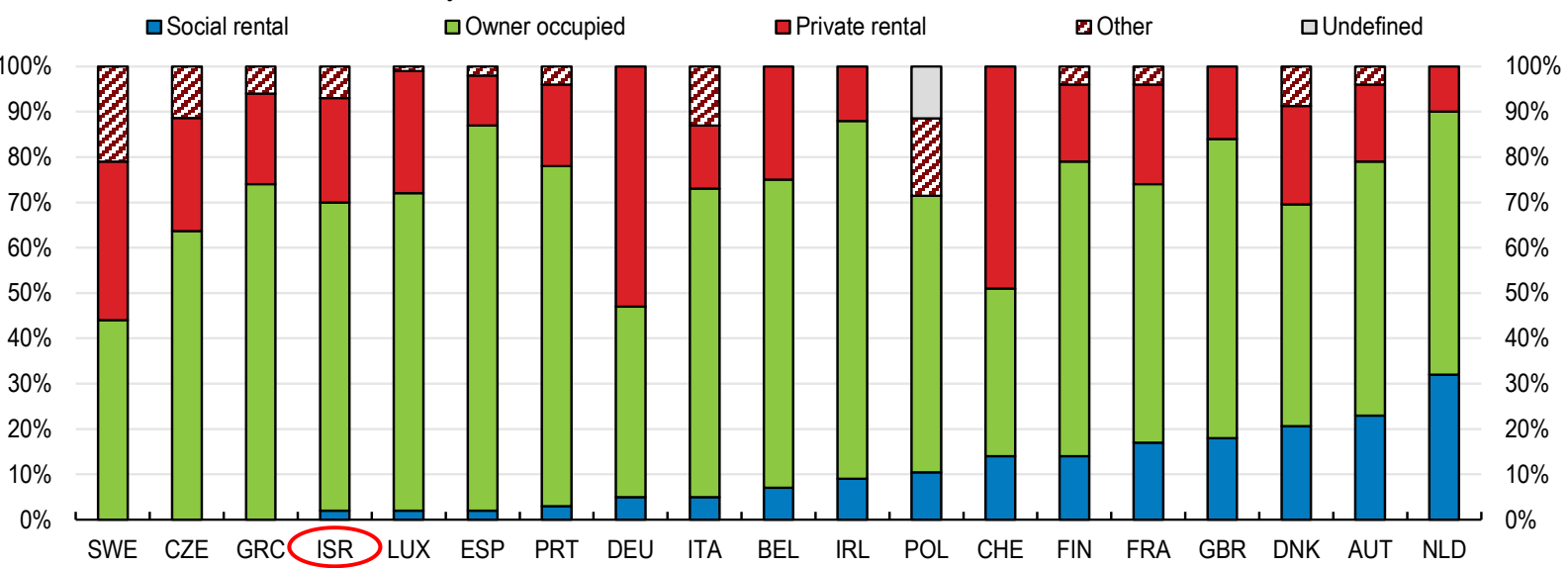

Note: "Other" includes residential units such as sheltered housing, student dormitories and cooperatively owned apartments. Public housing in Sweden, estimated at $20 \%$, is not defined as "social housing" since it is intended for the entire population and therefore included in "Other." In the Czech Republic, too, no homes are defined as "social housing," but 6-7\% are public housing, i.e., apartments owned and leased by the local authorities.

Source: Adva Center (2017), "Public Housing Option: Adva Center's Response to the Housing Crisis in Israel".

StatLink 제프 https://doi.org/10.1787/888934153122

Moreover, public housing is mainly located in peripheral areas and in neighbourhoods with low socioeconomic status far from employment centres, which are usually clustered together and have developed into areas of distress (Bol, 2019; Figure 15). International evidence shows that this can result in significant disparities in the quality of and access to education and in employment outcomes as well as in access to transit networks and public services (e.g. Galster, 2007; Gibbons, 2002; Andrews et al., 2011). American children growing up in poor-quality neighbourhoods perform less well in school and earn less as adults (Chetty et al., 2015). 
One way forward to increase the supply of public housing for needier households is by frequent reassessment of eligibility, with appropriate actions if the household's situation has changed. Today, yearly rental contracts for social housing units in Israel are renewed automatically, although the subsidised rent may change according to changes in the financial state of the tenants. In New Zealand, for example, in a pilot fixed-term tenancy programme in public housing, tenants who are found to be no longer eligible for social rental housing and able to move are helped to find an alternative solution. In France tenants have to leave when their income is for two years in a row $150 \%$ above the eligible revenue ceiling for housing financed through a social housing loan (OECD, 2017c). At the same time, the government should consider abolishing its policy of selling public housing dwellings to tenants to keep its stock of public housing.

\section{Figure 15. Social housing is located mostly in areas with weak economic activity}

Public housing units by district, $\%$ of total

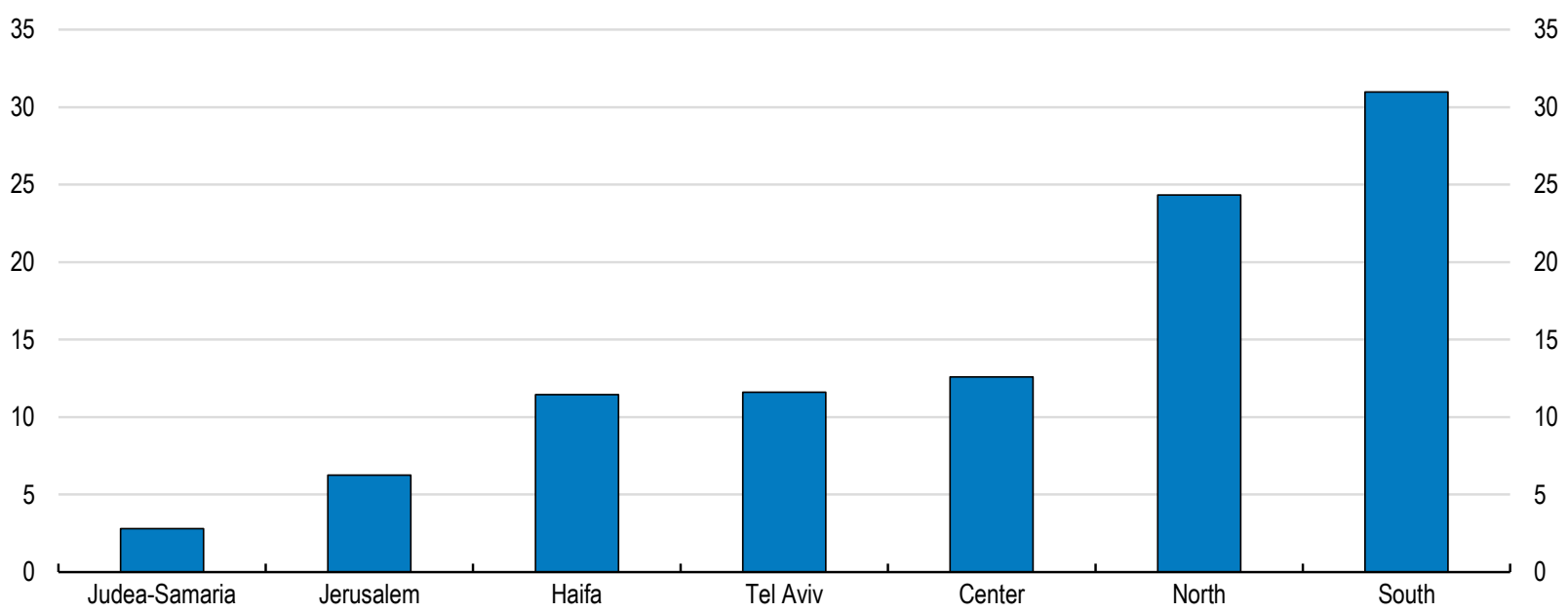

Source: Ministry of Construction and Housing.

StatLink त्ताज्य https://doi.org/10.1787/888934153141

A more effective housing-assistance policy would focus on helping households maximise their socioeconomic potential and reduce the segregation of poor population groups. Living in public housing may impair geographical mobility and work incentives because the dwellings are generally far from employment areas. Therefore, public housing should be targeted at the most disadvantaged families and should be built in areas close to employment centres. This method of housing support can be coupled with support services to help families adapt to the new community and reinforce employment incentives. Successful projects in Spain and the Czech Republic have helped families to resettle, providing subsidised rental housing and packages of social support to adjust to the new environment and livelihoods (Gatti et al., 2016; Housing First, 2018). Besides public housing, which should target the most disadvantaged families, housing assistance through rent subsidies should be strengthened instead, as it can have fewer distortive effects on residential mobility than social housing and improve affordability in the private rental sector.

\section{Regional development policy should continue to free up public land in the centre}

Similar to other countries, Israel is experiencing internal migration from peripheral regions to the centre, particularly among youth and the well educated (Figure 16). This weakens the periphery and creates pressure on infrastructure and housing in the centre.

Therefore, principles that have guided regional development policies in Israel in the last decade have included dispersion of the population from the country's centre to its northern and southern regions. For example, the Law for the Encouragement of Capital Investment provides grants to exporting firms in the 
periphery to promote productivity, process innovation and employment in the periphery. The government also provides income tax benefits to residents of around 400 outlying and near-border areas to increase the attractiveness of poorer regions and encourage migration from richer regions. There are also grants for high-tech companies that move to Beer Sheva, a city in the south.

\section{Figure 16. Extent of change in population aged 15-29 during the decade 2005-15}

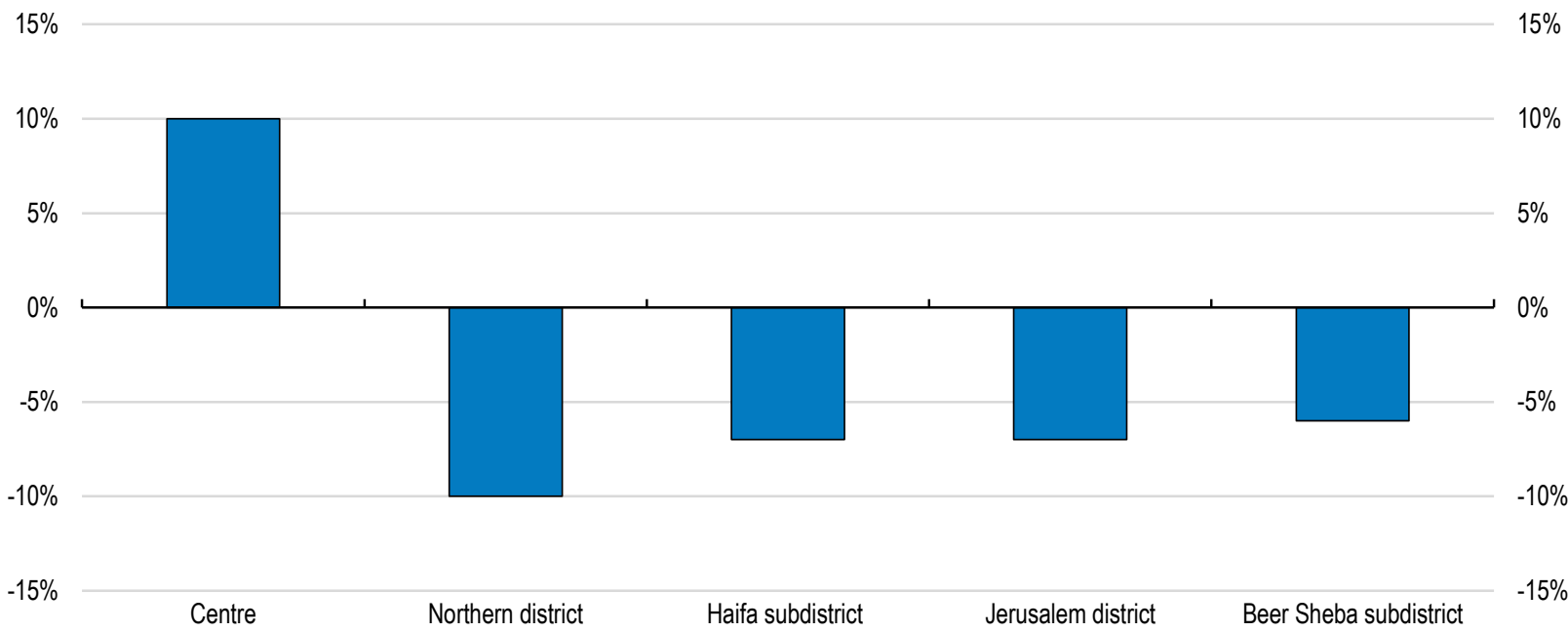

Source: Israel Central Bureau of Statistics.

However, research by the Bank of Israel finds little evidence that the tax credits encourage migration to poorer regions (Bol, 2015). In addition, they are prone to abuse. The same research shows that the number of residents who are registered in a region but do not actually live there is higher in areas that benefit from the credits than in other regions. Furthermore, the income of these "fictitious" residents of areas that benefit from the credit is substantially higher than actual residents' income, suggesting that tax incentives play a role in wrongfully registering in these regions.

The demand for housing remains high in the central region, with a shortage of land available for construction. Almost 60 percent of households reside in the areas in high demand-the Centre, Tel Aviv and Jerusalem -but these areas account for only $14 \%$ of the country's area, which means that they have little available land. Therefore, the government is rightly trying to find available land in the centre. The relocation of military bases from the Tel Aviv district will free up land for constructing about 60000 housing units - with a total fiscal cost of NIS 5.3 billion for 2015-27. The government should continue with its effort to free up public land in high-demand areas occupied by various public entities, including the Israeli Defence Force, local authorities, and agricultural and industrial bodies.

\section{Low skills can be another barrier to growth in lagging localities}

Human capital has a strong impact on regional growth and income (OECD, 2009a). Increasing the quality of education would improve the employability of the labour force in economically lagging municipalities, and a higher skilled workforce would also make lagging municipalities more attractive to firms.

However, localities in Israel differ considerably in the quality of their schools and the attractiveness of their local labour markets, and many risk becoming low-skill traps. Low-skilled workers become concentrated in some areas because housing is less expensive. Employers who require highly developed skills are less willing to invest there and offer high-skilled jobs. Therefore, local workers have no incentive to acquire additional training or higher education and those who do will tend to leave these regions. Indeed, poorer localities in Israel have a less educated population (Figure 17, Panels A and B). Analysis by the Bank of 
Israel confirms that both supply and demand for highly skilled people is concentrated in the Tel Aviv and central regions. In contrast, in the southern and northern regions, the proportion of educated individuals is small, as is the demand for highly skilled workers (Panel C).

\section{Figure 17. Poorer socio-economic areas have less skilled labour}

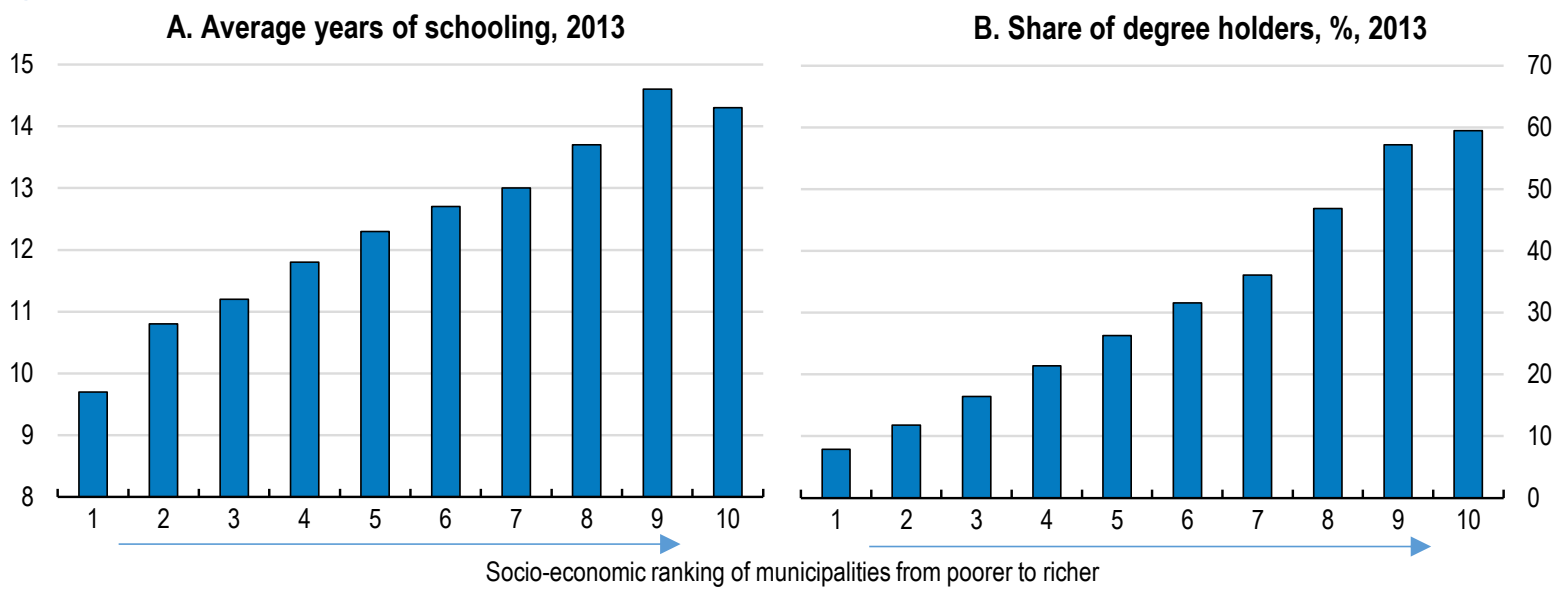

C. University graduates in prime working ages (15-64) and academic or managerial occupations in each region, 2016

Residents employed in academic or managerial occupations

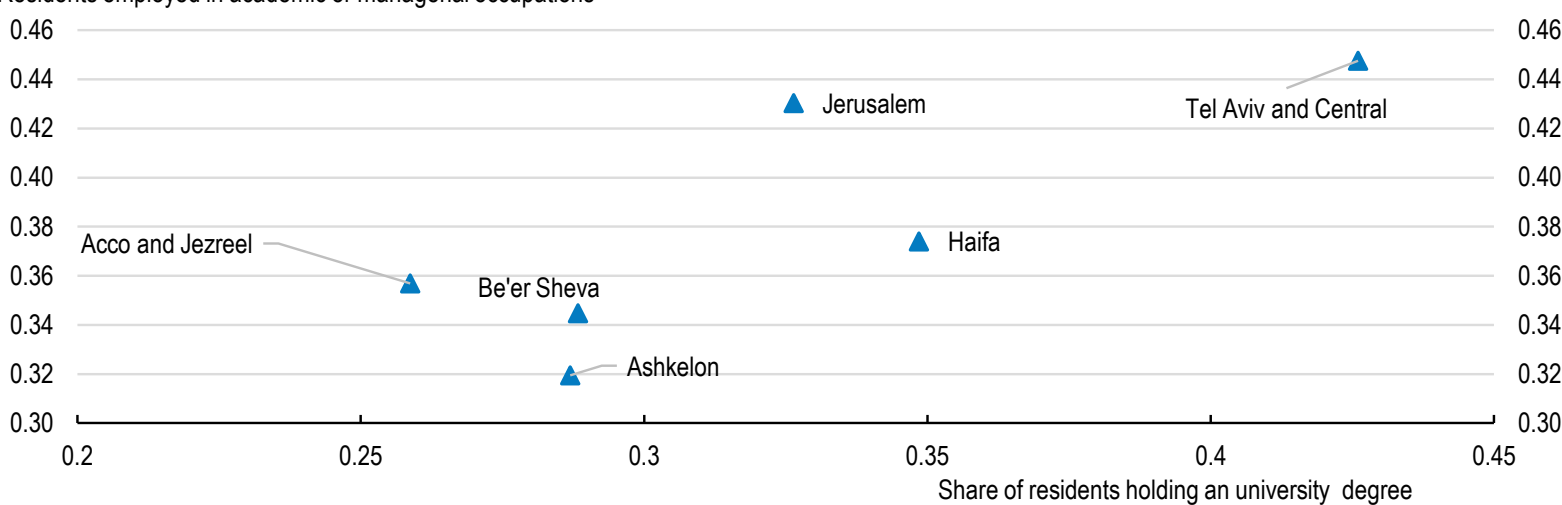

Source: D. Chernichovsky, B. Bisharat, L. Bowers, A. Brill and C. Sharony (2017), "The Health of the Arab Israeli Population", Taub Center, Jerusalem, http://taubcenter.org.il/wp-content/files_mf/healthofthearabisraelipopulation.pdf.

StatLink ज्ञाs https://doi.org/10.1787/888934153179

Moreover, the existence of multiple school streams in Israel reinforces geographic segregation along religious/community lines and hinders mobility between regions. There are four different school streams: (i) for Arabic speakers, (ii) for the Haredi community, (iii) religious and (iv) secular. In schools in the Arab cities the instructional language is Arabic, and almost all teachers are Arabs. In the Haredi stream boys study mainly religion and have only basic instruction in subjects like English or math. This fragmented education system weakens skills formation and contributes to Israel having the largest dispersion in educational outcomes in the OECD (OECD, 2018c). Moreover, the new 2018 PISA results suggest that the variation between schools is the highest in the OECD and the differences between Arab-Israeli and Hebrew streams have increased (OECD, 2019b). This is in contrast with the best performing education systems across OECD countries, which successfully combine high quality with little dispersion (OECD, 2012). 
Overall spending per student, including municipal and central government spending, is much lower for schools in poorer and disadvantaged areas (Figure 18). Central government funding does not target schools in poorer areas sufficiently. Additional financing for socio-economically weak schools is low. Per student spending has been $12 \%$ above average in the (predominantly) Jewish local authorities, while predominantly Arabs local authorities have spent 36\% less than average (OECD, 2020b).

\section{Figure 18. Education spending is much lower in the poorer localities}

Spending per student in kindergarten, primary school, and secondary schools ${ }^{1}, 2016$

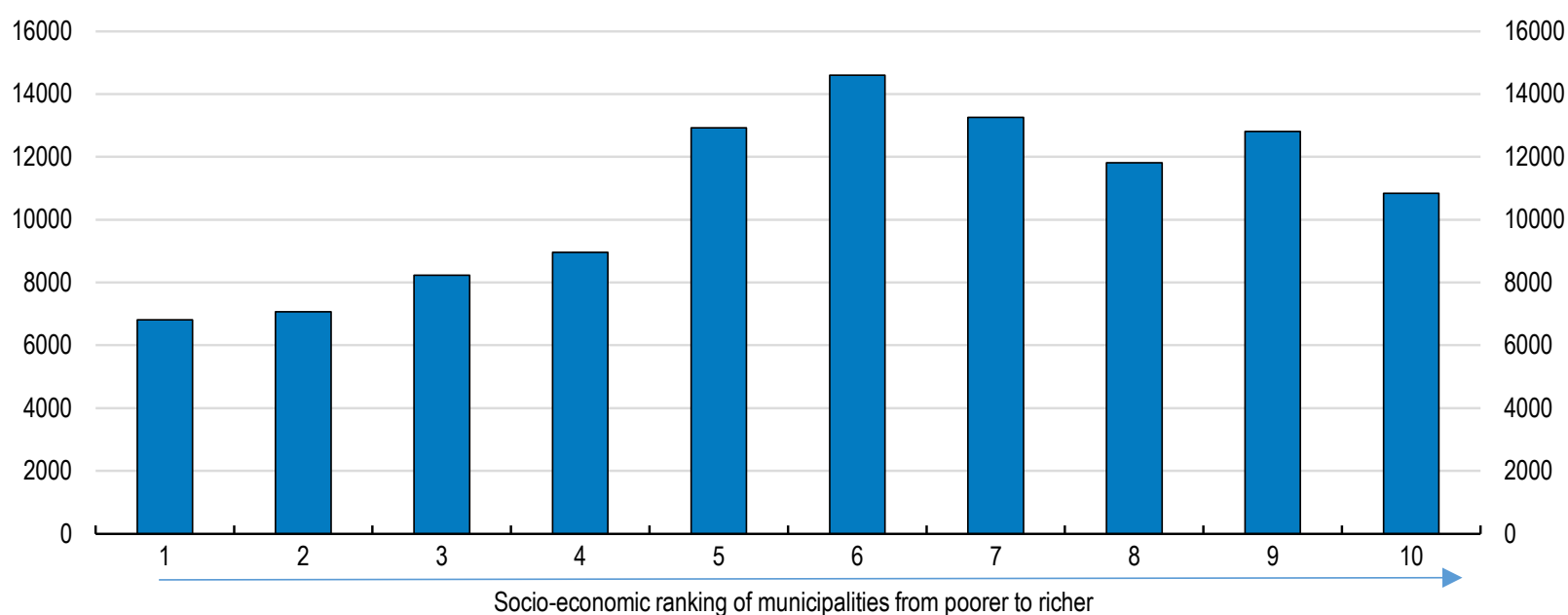

1. Based on municipal reporting.

Source: OECD (2020), "A review of local government finance in Israel: Reforming the Arnona system" (forthcoming); Israel Central Bureau of Statistics.

StatLink הत्ञाs https://doi.org/10.1787/888934153198

In many other OECD countries the financing of schools with weaker socio-economic profiles is much more generous. In Denmark, for example, municipalities with a relatively disadvantaged population receive more resources for education than others: the top-up funding for schools with disadvantaged groups represent one quarter of the overall budget for primary and lower secondary schools (Houlberg et al., 2016). In Chile a weighted voucher system provides $50 \%$ more resources for students from poor socio-economic backgrounds (Elacqua, 2012). Funding should be boosted for schools with a high percentage of disadvantaged students and should be subject to regular monitoring and evaluation. Schools' physical structures and the quality of the teaching staff should provide favourable conditions for students from different backgrounds to succeed.

In order to reduce the differences in skills between localities and overcome skills barriers, the government should focus on: (i) improving pre-school education, (ii) recruiting higher-quality teachers and (iii) reducing the gaps between the different streams (see below).

\section{Reducing the skills gap between regions should start early on}

Improving educational outcomes in poor localities should focus on pre-school education. Results from the OECD's PISA tests for 15 year-olds suggest that gaps in educational outcomes between Arab-Israeli students and the rest of the population are significant, amounting to 4 years of schooling. This suggests that the gap is already relatively high at the age of 15 , so to close the gap interventions should start much earlier. 
Participation in high-quality early childhood education and care can significantly improve children's development, benefiting their health and well-being (OECD, 2018d). Indeed, children who attend preschool education are less likely to become low-performing students in most OECD member countries, with the impact in Israel being one of the largest (Figure 19). Therefore, allocating funding to high-quality preschool facilities is likely to help prevent the need for more costly interventions at later stages of the schooling process. Targeting higher participation of disadvantaged children is crucial for attaining both efficiency and equity in education.

\section{Figure 19. Students who attended pre-school education are less likely to become low-performers}

Proportion of low-performers among 15 year-old students according to the number of years spent in early childhood education, 2015, \%

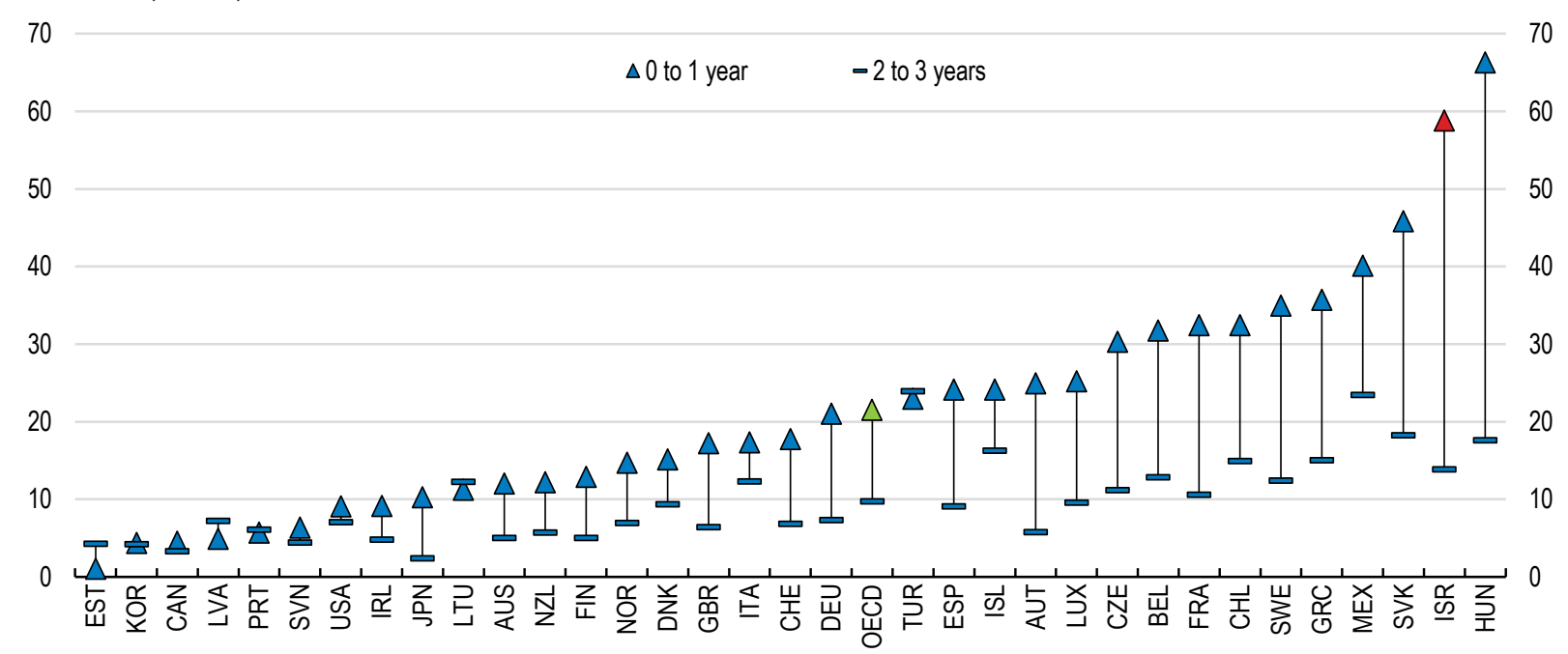

Source: OECD PISA online education database.

StatLink त्ञाज https://doi.org/10.1787/888934153217

Israel has made significant progress in increasing participation in pre-school education. In 2012-13 Israel introduced compulsory education from the age of 3-4. Since then the number of children enrolled in public pre-schools and afternoon programmes has increased, along with an overall decline in parental payments for pre-school education (Shraberman and Blass, 2017). The responsibility for implementation and financing is divided between the Ministry of Education and local authorities. But weaker localities do not always have the necessary resources to build new buildings and ensure places for all 3-4 year-olds. In particular, one-fifth of Arab children aged 3-4 do not participate in pre-school education (double the rate among the rest of the population). The implementation of compulsory pre-school education for 3-4 yearolds led to over-crowded pre-school classrooms. Funding per child is half the level in OECD countries. Avoiding a low-quality pre-school experience is important, because of the risk of detrimental effects on development and learning (OECD, 2018e).

Moreover, despite positive efforts to improve access to day-care centres and family-based frameworks for children aged 0-3, access is still limited (Shavit et al., 2018). Only a fifth of children aged 0-3 attend daycare centres or family daycare, and only half as many do so among the Arab population. Israel has no specific authority that coordinates services and supervises the quality of care provided to young children; in other OECD countries child development and outcomes are monitored alongside staff quality (OECD, 2017d). Only those local authorities who have the available budgets operate daycare centres, because there is no obligation for the local authorities to establish such centres.

Additional educational funding could help increase the supply of high-quality pre-school programmes and allow easier access to daycare centres for children whose parents do not regularly and continuously 
participate in the labour market. Improving staff quality should be at the centre of these efforts by raising minimum requirements and providing adequate training and working conditions. Special emphasis is called for to develop a system of daycare centres to serve the Arab-Israeli population.

\section{Improving teacher quality in poorer regions}

Empirical research suggests that teacher quality is the single most important driver of student performance, strong enough to close the achievement gap between advantaged and disadvantaged students (Chetty et al., 2014). However, as the previous Economic Survey argued, the quality of Israeli teachers is poor. There are a large number of uncertified teachers, and teacher skills are among the weakest in the OECD (OECD, 2018c). Moreover, teacher quality varies significantly across regions. Teacher quality in areas where many people have a relatively low socio-economic background is significantly lower than in economically stronger localities, though the gap has narrowed over the past decade (Figure 20). Arab teachers' scores in psychometric tests are much worse, which also reflects the overall weak performance of Arab-Israelis in these tests. Poorly qualified teachers in US schools serving disadvantaged students tend to have a negative impact on student performance (Darling-Hammond, 2010), further diminishing their students' chances of success.

\section{Figure 20. Schools in poorer localities have weaker teachers}

Average score achieved by teachers on psychometric tests by socio-economic cluster of the school's locality

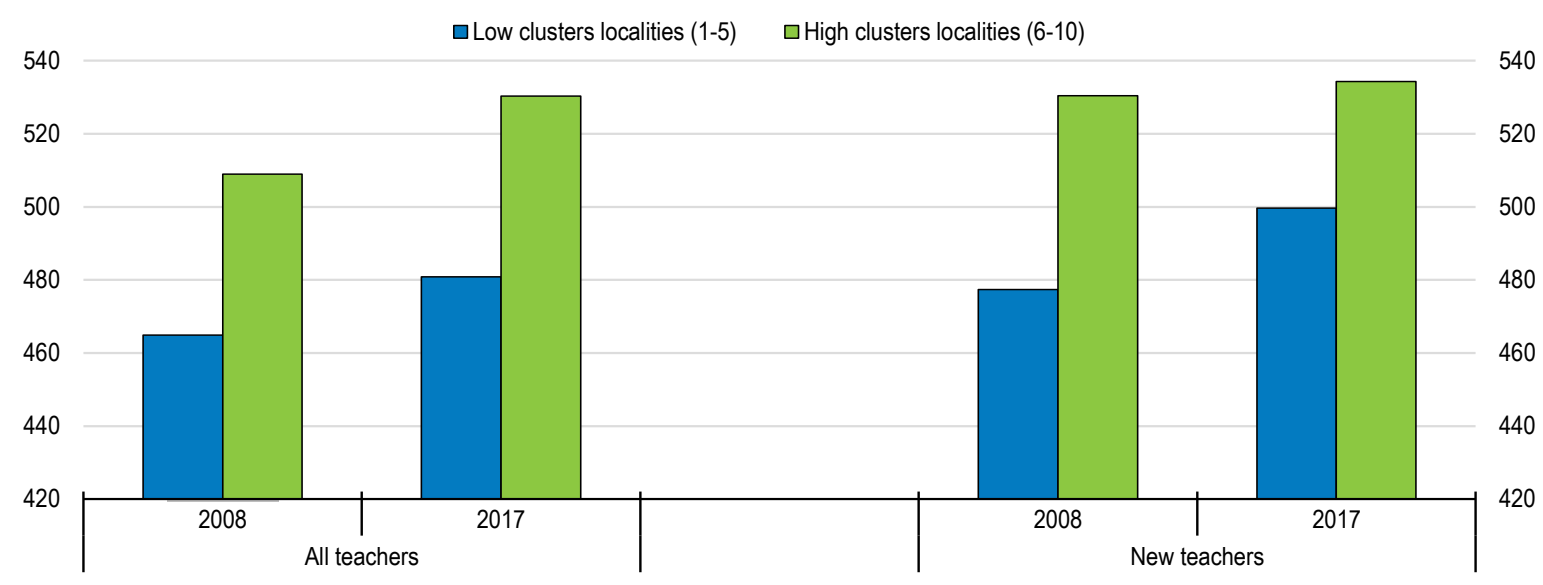

Source: Bank of Israel (2017), Annual Report - 2017, March.

In order to reduce regional disparities the focus should be on attracting the best teachers to disadvantaged schools and poorer regions. This is challenging, as experience from other countries shows that teachers' least-preferred options are schools in rural and remote settings, together with schools with higher proportions of disadvantaged children and children who speak minority languages (OECD, 2005). Today there is almost no incentive for Israeli teachers to teach in disadvantaged schools. Their wages are almost identical across regions and across sectors (Blass and Bleikh, 2018). Several other OECD countries provide financial incentives to compensate teachers for working in poorer areas (OECD, 2014b). In the United States these wage bonuses have helped reduce turnover rates of teachers in disadvantaged schools (Clotfelter et al., 2008). Empirical research has shown that a $30-50 \%$ salary premium is required to convince teachers to stay in disadvantaged schools (Hanushek et al., 2004).

Financial incentives should be accompanied by better working conditions, which are key for better outcomes, such as smaller class sizes or more teaching assistants (OECD, 2012). For example, in addition to a salary premium Korea offers multiple incentives to candidates working in high-needs schools, such as 
smaller class sizes and additional credits towards future promotion. Faster promotion to leadership positions can be achieved for those with a proven track record of helping disadvantaged students progress. In addition, a teacher-evaluation system should be promoted to help schools with many students from weak backgrounds to retain their existing high-quality teachers. Israel has no comprehensive teacherevaluation system (Bol, 2017). Such a system could improve teaching quality significantly and also make the teaching profession more attractive (OECD, 2009a; Fryer, 2016). French empirical research has confirmed that students of teachers who are assessed positively in such a review experience faster learning progress than others, with a particularly strong effect for disadvantaged students (Benhenda, 2014). An evaluation system could also be used to identify good teachers, who could then qualify for promotion and higher salaries, particularly when they teach many poor children.

\section{Building bridges between different educational streams}

Student streaming and segregation can have a significant impact on equity; there is therefore a need to reduce the differences between individual streams as much as possible (OECD, 2018a). While merging all streams into one might be challenging, efforts should focus on building bridges between the streams.

Additional financing should concentrate on promoting pathways between the Arabic- and Hebrew-speaking streams. Promotion of additional Hebrew courses in the Arab stream is important, since poor command of the Hebrew language prevents the Arab population from job mobility and from fully integrating into the Israeli labour market (OECD, 2018c). Surveys confirm that the vast majority of Arab students believe that better knowledge of Hebrew will help their careers (Marom, 2015).

It is also important to encourage Jewish teachers to teach Hebrew and other subjects in Arab schools and vice versa. The number of Arab teachers in Hebrew-speaking streams has almost doubled since 2012, but they still represent only around $5 \%$ of all the teachers in Israel. Pilot programmes placing Jewish teachers in Arab schools and Arab teachers in Jewish schools to teach their native languages have proved to be effective (Schneider, 2016). Another way to build bridges between the streams is to promote bilingual schools (Box 3). These schools should be monitored in terms of equity and outcomes; if they prove effective, the government should increase funding for them.

\section{Box 3. Bilingual schools in Israel}

In recent years parent groups and non-governmental organisations have created bilingual schools, which aim to create an egalitarian, bilingual educational environment of mutual respect and equality for both groups. In bilingual educational institutions, Hebrew and Arabic are used equally as languages of instruction, and two teachers are in the classroom simultaneously, each teaching in a different language.

Since bilingual schools staff each class with a pair of teachers, their operating costs are higher than those in mainstream schools. The difference between the Ministry of Education's allocation and actual expenditures is made up by donations and tuition fees (Shwed et al., 2014).

Currently, eight schools (seven elementary schools and one high school) and at least 15 kindergartens in Israel have defined themselves as bilingual. The number of students increased from 1000 in 2013 to around 1700 in 2018 but remains marginal, given that there are around 1.2 million students in Israel (KRIC, 2019).

Another way to reduce the skills gaps between different cities and towns is to promote the teaching of English, maths, sciences and other secular subjects in Haredi schools. The Haredi education stream emphasises studying religious subjects, and at the age of 13 boys enter yeshivas, which focus on the study of traditional religious texts, and reject formal education in secular subjects. As a result, many Haredi men 
often lack basic skills, notably in mathematics and English. As was recommended in previous Surveys, teaching of core subjects in Haredi schools should be strengthened (OECD, 2018c). Many previous attempts failed for political reasons, but the authorities should redouble their efforts to introduce core subjects in the Haredi curriculum in order to improve integration of the Haredi community into the wider Israeli society.

\section{The local authority funding system exacerbates regional differences}

The success of education, transport and housing policies will depend heavily on their funding and implementation on the local level. Empirical research confirms that better schools, good local government and effective policies to realise national priorities are the right means to improve the outcomes of residents living in poor municipalities (Justman and Spivak, 2004). However, the ability of municipalities to implement policies effectively depends crucially on their fiscal position.

\section{Economically strong municipalities benefit from high local revenues}

Local government revenue consists of government transfers and municipal income. The composition of these two revenue sources varies from authority to authority and depends on municipalities' tax-raising capacity. The largest source of municipal income is the local property tax, which accounts for $80 \%$ of the total tax revenue raised by local authorities. Israel's local authorities have only limited ability to adjust tax rates, and their tax autonomy is the weakest in the OECD (Blöchliger, 2015; Figure 21). The local property tax rates must remain within a certain range supervised by the central government. Moreover, a local authority that would like to modify its property tax rate must receive the approval of both the Ministry of the Interior and the Ministry of Finance. In 2018 all the approved requests involved only marginal adjustments (OECD, 2019a).

\section{Figure 21. Local tax autonomy in Israel is weak}

Percentage of local tax revenue decided by central government, 2014

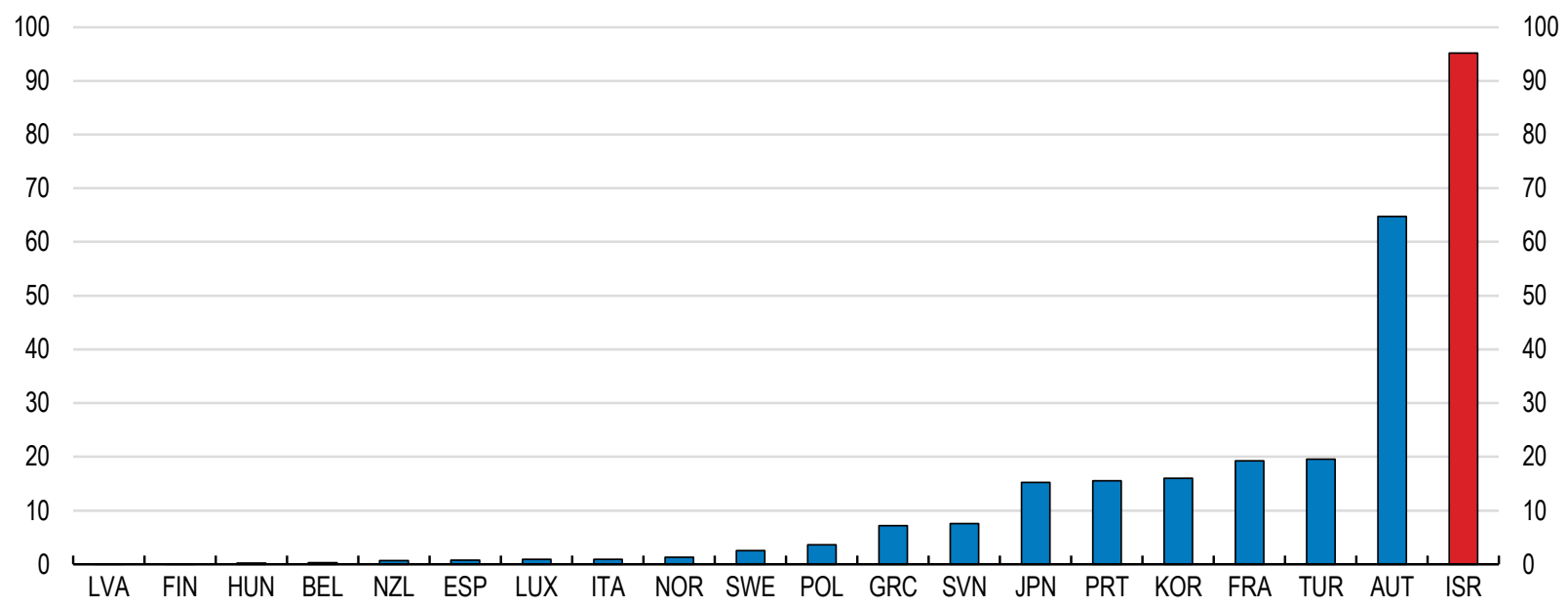

Source: OECD Fiscal Decentralisation database.

Economically strong municipalities have higher revenue from property taxes than others (Figure 22). First, they have many more commercial and industrial parks, as economic activity is concentrated in metropolitan areas and economic centres. The property tax charged for non-residential land is much higher than that on residential properties (see above). Second, residential property tax collection as a proportion of what is owed is much lower in poorer municipalities, less than $50 \%$, while it is around $90 \%$ in the wealthiest 
municipalities (Figure 23). These differences are mainly due to tax breaks, exemptions and discounts for low-income earners, but tax avoidance in poorer municipalities also plays a role (Brender, 2007). Not only have poor municipalities less in the way of commercial property and receive less from non-residential tax revenues, but they also receive less from residential taxes due to tax breaks and discounts, which are set by the central government.

Figure 22. Local authority revenues are much smaller in poorer municipalities Thousand NIS per resident, 2017

\section{A. Average income from property tax}

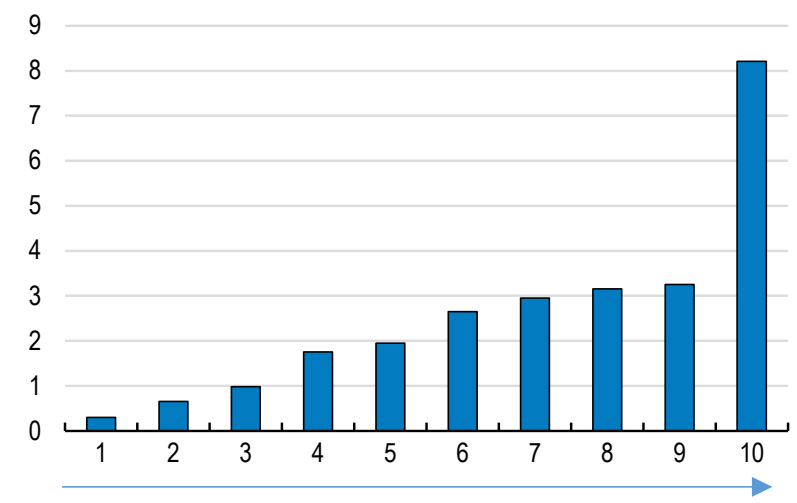

Ranking of municipalities from poorer (1) to richer (10)
B. Average municipal property tax income according to their dominant religious group

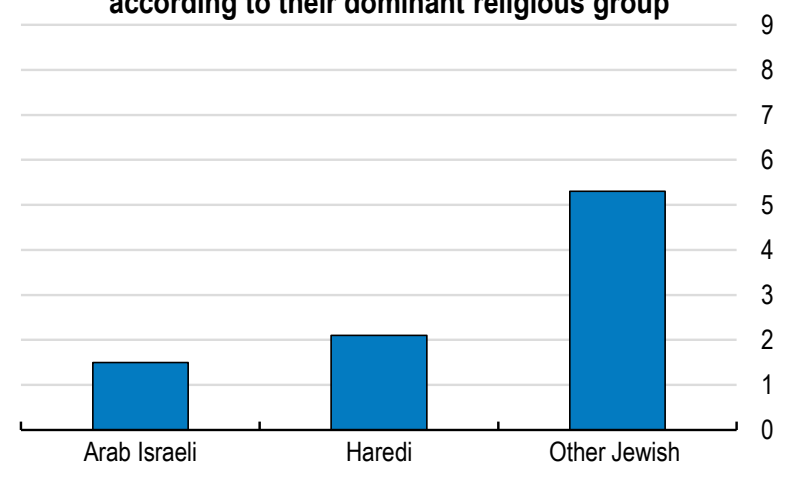

Source: OECD (2020), "A review of local government finance in Israel: Reforming the Arnona system" (forthcoming); Israel Central Bureau of Statistics.

StatLink הत्ञाs https://doi.org/10.1787/888934153274

\section{Figure 23. Poorer municipalities have weaker tax collection}

Residential property tax collection rate (\% of what is owed)

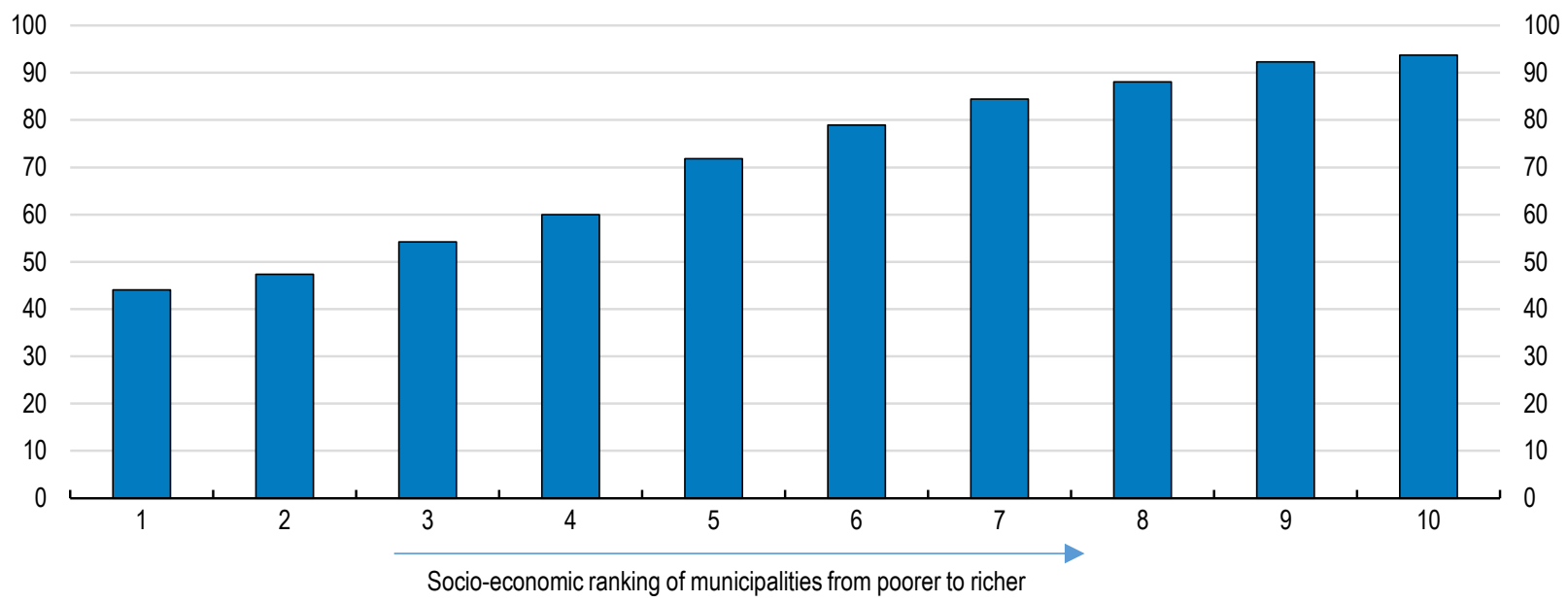

Source: OECD (2020), "A review of local government finance in Israel: Reforming the Arnona system", (forthcoming). 


\section{Box 4. Local authorities in Israel}

Israel has one sub-national level of government, composed of 257 local authorities - 76 municipalities (cities with at least 20000 inhabitants), 125 local councils (towns with fewer than 20000 inhabitants) and 56 regional councils. Local authorities are elected through direct elections and have administrative and governmental power in their jurisdiction. The average municipality has around 35000 inhabitants, 3.5 times the average in OECD countries (OECD, 2020b).

In terms of spending responsibilities Israel is a centralised country with a relatively small amount of local government expenditures. In 2016 local government expenditures stood at $5.5 \%$ of GDP, below the OECD average for unitary countries (13.4\% of GDP). Local authorities have been delegated responsibilities by the central government for education, social services and infrastructure. More than half of their expenditure goes to education and social protection. Local government revenues are comprised mainly of government transfers and own income, mainly from property tax (see below).

\section{Structure of local revenues and expenditures in Israel}

\section{Revenue sources}

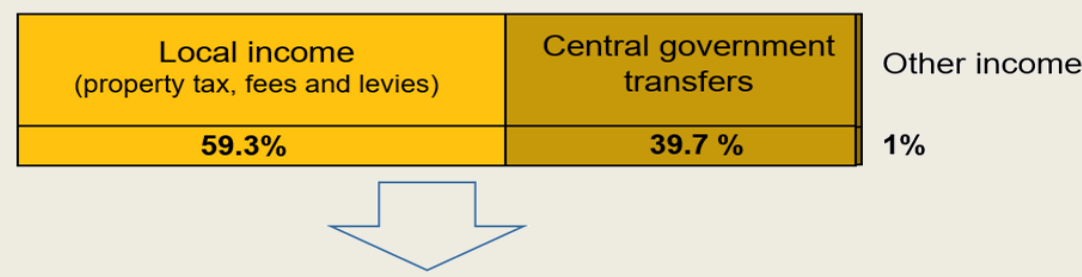

\section{Local government}

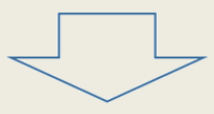

Expenditures

\begin{tabular}{|c|c|c|c|c|}
\hline Education & $\begin{array}{c}\text { Recreation, } \\
\text { culture and } \\
\text { religion/ } \\
\text { environment }\end{array}$ & $\begin{array}{c}\text { Other public } \\
\text { services } \\
\text { (housing, defence, } \\
\text { general services) }\end{array}$ & $\begin{array}{c}\text { Social } \\
\text { protection }\end{array}$ & $\begin{array}{c}\text { Economic affairs } \\
\text { /transport }\end{array}$ \\
\hline $35.9 \%$ & $\mathbf{1 9 . 9} \%$ & $\mathbf{1 9 . 3} \%$ & $\mathbf{1 7 . 4 \%}$ & $\mathbf{7 . 4 \%}$ \\
\hline
\end{tabular}

Source: OECD (2020), "A review of local government finance in Israel: Reforming the Arnona system" (forthcoming).

\section{Central government transfers are too small to close local revenue gaps}

In order to narrow the income gap between local governments, the government provides transfers, which consist of:

- Service grants for education and welfare, which are used for delegated responsibilities in education and social welfare; yet local governments have some discretion as to how they spend these funds. These Service grants also include a matching component, whereby local governments are required to match the additional grant with their own resources.

- The Balancing grant is an equalisation fund, which provides more funding to poorer municipalities. The grant is calculated as the difference between normative expenses set by the central government and potential revenues.

- The Equalisation Fund is levied on government-owned property and distributed to municipalities according to: (i) the municipality's socio-economic index, (ii) its lack of non-residential property, (iii) its peripherality and (iv) the quality of its financial management (OECD, 2019a). 
While the transfers help to reduce the differences in resources among local governments, the differences remain significant (Mofkadi and Shalem, 2018). The wealthiest municipality still has 12 times higher overall revenue per capita than the poorest (Table 2). The effect of equalisation funds in other countries is much more substantial: pre-equalisation disparities are reduced by roughly two-thirds on average across countries (OECD, 2013), but in Israel by only one-third. The differences in overall revenues in Israel even after the impact of the grants remain the highest in the OECD (Figure 24).

Differences in resources mean that poorer municipalities can find it difficult to provide adequate service levels for their residents. Expenditure per capita on education and welfare is lower in poorer regions, and residents of Haredi and Arab municipalities receive much lower overall expenditure per capita (Figure 25). The differences in public-service provision is striking, given that poorer and rural areas have greater needs and would require higher spending to enhance convergence and as a means to escape poverty. Poor municipalities can find themselves in a vicious circle in which weak economic activity leads to less tax revenue and lower-quality services, which hampers local development and results in further weakness in economic activity.

Table 2. The impact of grants on fiscal disparities among Israeli local governments, 2016

\begin{tabular}{l|c|c}
\hline & Total property tax & Total property tax \& all grants \\
\hline Average & 3,294 & 7,134 \\
\hline Standard Deviation & 2,807 & 3,953 \\
\hline Coefficient of Variation & 0.85 & 0.55 \\
\hline Minimum & 73 & 2,977 \\
\hline Maximum & 29,824 & 37,272 \\
\hline Gini Coefficient & 0.333 & 0.221 \\
\hline
\end{tabular}

Source: OECD (2020), "A review of local government finance in Israel: Reforming the Arnona system", forthcoming.

Figure 24. The differences between municipalities remain large even after transfers

Gini coefficient before and after transfers

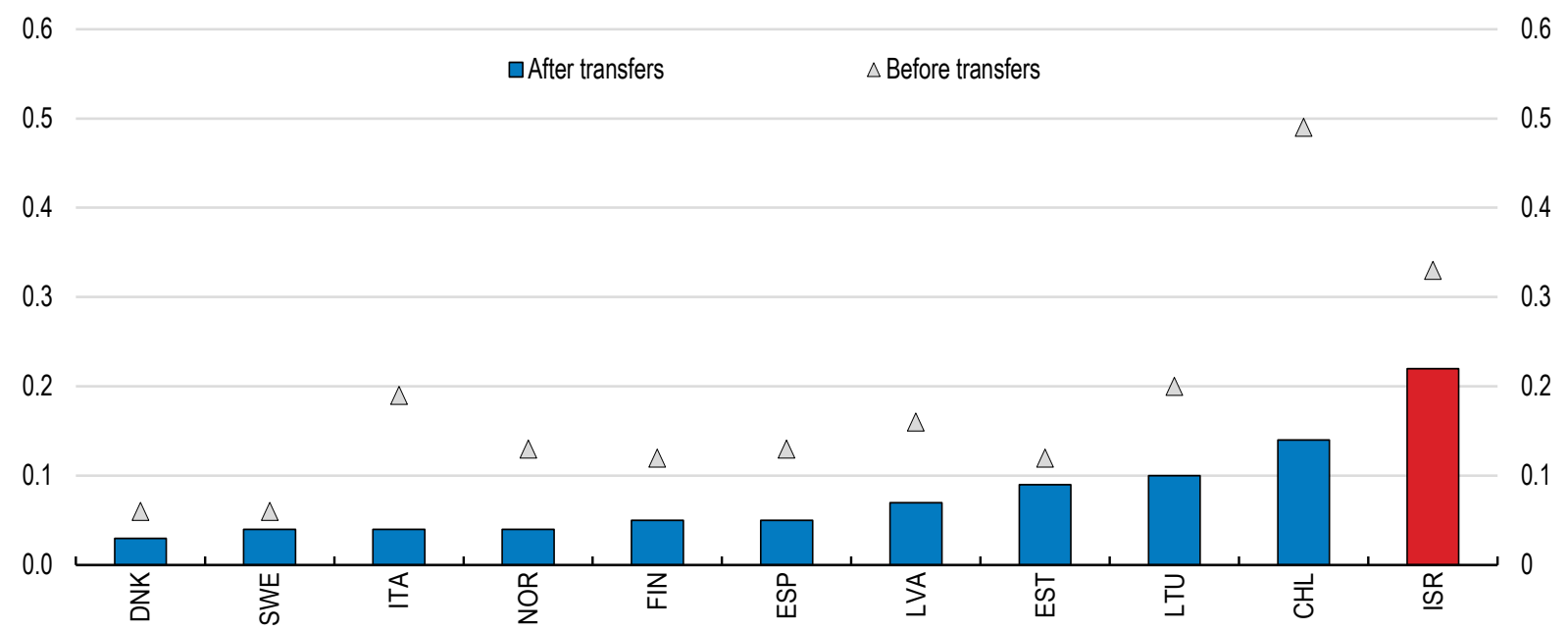

Note: Data for Estonia, Israel, Latvia, Lithuania and Sweden refer to 2017; data for Chile, Denmark, Finland, Italy, Norway and Spain to 2012. Source: H. Blöchliger (2014), "Fiscal equalisation - a cross country perspective", Paper prepared for the conference on "Fiscal Equalisation", Berlin, 26-27 June, OECD (2020), "A review of local government finance in Israel: Reforming the Arnona system", forthcoming; OECD (2020), "Fiscal equalisation - a cross country perspective" (forthcoming). 
Figure 25. Poorer municipalities have less public-service provision

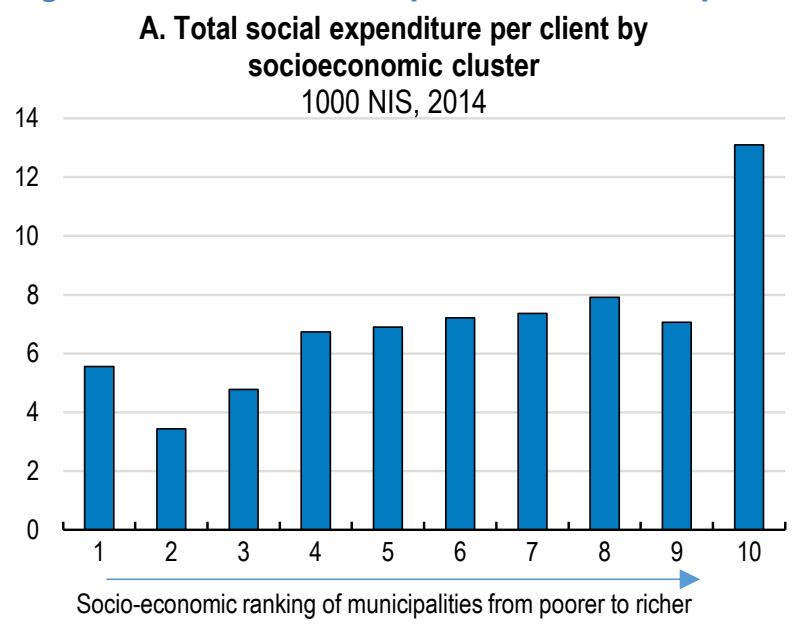

B. Expenditure per capita 1000 NIS, 2014

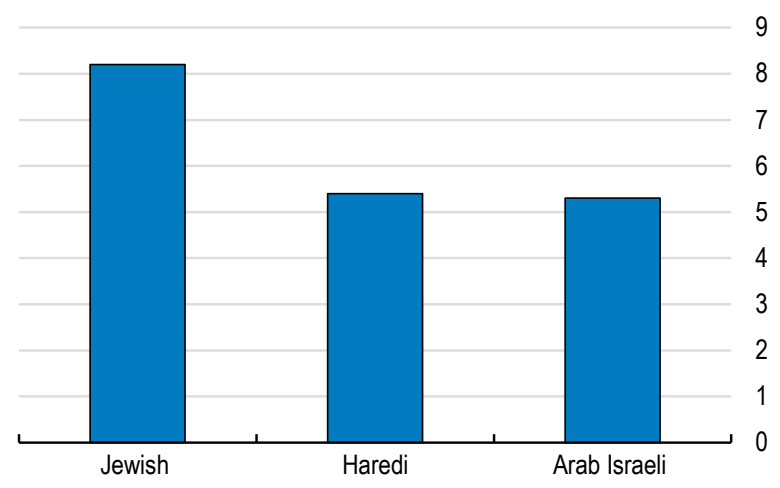

Source: Israel Central Bureau of Statistics; OECD (2017), Spatial Planning and Policy in Israel: The Cases of Netanya and Umm al-Fahm, OECD Publishing, Paris.; J. Gal, S. Madhala and H. Bleich (2017):, "Social service budgeting in local authorities", Taub Center, A chapter from The State of the Nation Report 2017.

StatLink 슈내 https://doi.org/10.1787/888934153331

At the same time poorer municipalities often run into fiscal difficulties. These municipalities have less revenue, but at the same time higher expenditure needs. Local municipalities are not allowed to run deficits, and the Ministry of the Interior provides special fiscal recovery grants to local authorities that have an accumulated deficit and are engaged in a fiscal recovery programme. The government categorises local municipalities in groups according to their fiscal stance and the quality of the services provided to their citizens. More than $60 \%$ of the municipalities with Jewish residents have fiscally strong and stable local authorities, while Arab-Israelis and Haredim overwhelmingly live in municipalities in recovery programmes due to accumulated deficits (Figure 26).

\section{Figure 26. Municipalities with disadvantaged groups have much worse fiscal outcomes ${ }^{1}$}

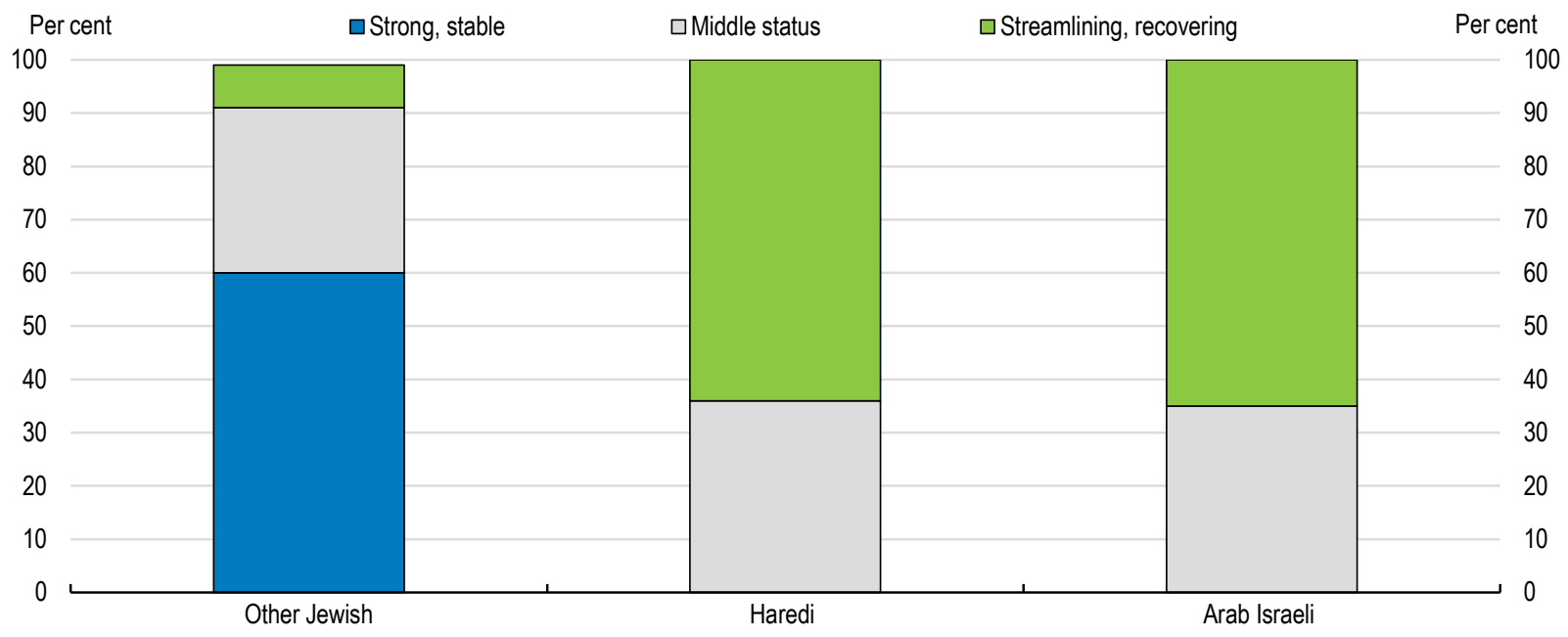

1. Strong or stable stands for balanced budget or fiscal deficit less or equal than $1 \%$ of income, Middle status, municipalities receiving loans but are run accordance to efficiency plans, Streamlining and Recovery means deficit over $17.5 \%$ and debt higher than $50 \%$ of the municipal income. Source: J. Gal, S. Madhala and H. Bleich (2017),: "Social service budgeting in local authorities", Taub Center, A chapter from The State of the Nation Report 2017. 
The government is aware of the problem, and reducing the differences between municipalities has been an important objective of the Ministry of Interior. In the recent years additional measures have been implemented to deal with it (Box 4). In response to the COVID-19 crises, the Ministry of Interior and Ministry of Finance provided a $25 \%$ discount in local property taxes for firms that were shut down during the lockdown (NIS 2.7 billion) and compensated local governments for the revenue shortfall differentiated according to the fiscal strength of the municipalities. Businesses experiencing a substantial decrease in their sales turnover will receive a refund for property tax expenses until the end of June 2021. In addition, the government allocated a regional grant for the city of Eilat and the municipality of Tiberias, whose income is reliant on tourism.

\section{Box 5. Additional actions to reduce economic discrepancies between local authorities}

- The balancing grant increased from 2013 through 2017 by half a billion shekels, resulting in a fairer distribution between local authorities.

- Seven permanent geographical committees have been established since 2017. They deal with municipal boundary changes and with the subsequent distribution of revenues from non-residential areas such as joint industrial zones or military bases. The local authorities have exchanged lands with a total area of $48.5 \mathrm{sq} . \mathrm{km}$ and a total of 160 million ILS in revenue were redistributed in order to reduce differences in resources between municipalities.

- The government has been assisting disadvantaged local authorities, those containing minorities and those in the periphery with a budget of NIS 7.2 billion. This assistance include Plan for the Development of Druze and Circassia Municipalities for 2016-2020, Government Activity Plan for the Financial Development of Minorities for 2016-2020.

- Several development instruments for local authorities have been set up. For example, "Youth for Local Government" is integrating high-quality human capital into disadvantaged local authorities. As of now, 210 graduates have been absorbed into 90 municipalities and regional clusters.

\section{The local fiscal framework needs to promote high-quality services in poorer municipalities}

The government should continue with its efforts to shrink these differences in resources as the gaps remain substantial. It should ensure that everybody has the same basic public-sector provision regardless where they are born. This will require higher funding for disadvantaged poorer areas. To finance these costs and to reduce significant differences in resources between municipalities, the government will have to strengthen its fiscal equalisation efforts.

One way forward could be a higher "compensation rate" from wealthier municipalities. In some OECD countries wealthier jurisdictions transfer part of their revenues to central government for redistribution (Box 6). Evidence from OECD countries shows that this type of equalisation is more effective than vertical equalisation as it has a higher equalisation effect per monetary unit (Blöchliger, 2015). For example, in the United Kingdom local government retains part of the revenues from the non-residential property tax, and the rest is transferred to the central government and redistributed as grants (Kim and Dougherty, 2018). Swedish municipalities and county councils whose income exceeds $110-115 \%$ of average tax capacity per capita have to pay an income equalisation charge to central government. In Norway municipalities with above $90 \%$ of average fiscal capacity do so. In Germany those localities with above-average fiscal capacities reallocate a portion of their revenue to localities with below-average fiscal capacity. The rate of equalisation declines as fiscal capacity rises, but the equalisation is held intentionally below $100 \%$ to stimulate the development of own-source revenues (OECD, 2020b). 
The matching component used in grants for social services should also be reconsidered. This requirement obliges local authorities to co-fund part of the total cost of these services along with the central government. Currently the matching component is the same for every municipality; for example, in social services central government covers $75 \%$ of the costs and municipalities cover the other $25 \%$. With these central government grants and their much higher tax revenues the wealthier municipalities can afford to expand their services. Therefore, the matching component should be reconsidered to better reflect differences in tax capacity between municipalities.

\section{Box 6. Equalisation systems in OECD countries}

In most OECD countries there are significant imbalances between different local authorities' fiscal capacity. Therefore, central governments provide fiscal equalisation funds to narrow these gaps. Equalisation arrangements can be either:

- Revenue vs cost equalisation: the equalisation fund aims either to reduce differences in tax-raising capacity or in the costs of providing public services.

- Vertical vs horizontal equalisation: equalisation is provided either by the central government to fill the gap between municipalities' finances, or wealthy jurisdictions directly provide resources to their poor counterparts.

In OECD countries the combination of vertical and cost equalisation systems is most common (Figure 27). The data for Israel are missing, but it is likely that it would be positioned in the bottom-right quadrant with very low horizontal equalisation, which suggests that there is room to improve equalisation through higher compensation from wealthier municipalities.

\section{Figure 27. Comparison of equalisation systems}

Revenue versus cost-based and horizontal versus vertical systems, as \% of total transfer flows

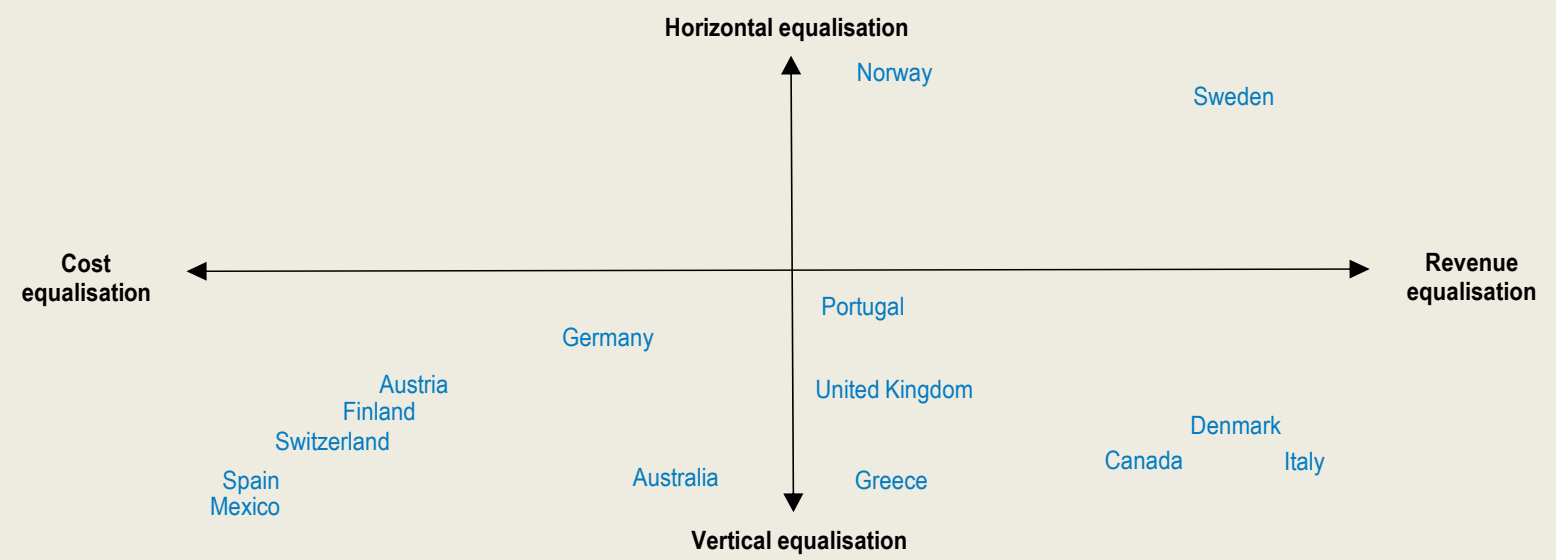

Source: H. Blöchliger (2014), "Fiscal equalisation - a cross country perspective", Paper prepared for the conference on "Fiscal Equalisation", Berlin, 26-27 June.

The government could also merge municipalities, which could entail large efficiency gains and help address the differences between municipalities. In the past, several attempts to reduce the number of municipalities failed for political reasons. Many OECD countries have merged their municipalities. For example, in Denmark mergers scaled up each level of government and the number of municipalities fell from 271 to 98 in 2007 (OECD, 2016b). The new municipalities received more competencies and resources. In Switzerland cantons encourage mergers with financial incentives and some cantons grants for evaluating a potential merger (OECD, 2016b). 
Widening inter-municipal cooperation and using more regional clusters and shared industrial zones is another option to improve efficiency. Inter-municipal co-operation has increased in OECD countries and provides benefits for both rural and metropolitan municipalities (OECD, 2018b; OECD, 2019d). There have been attempts in Israel to establish voluntary associations of neighbouring local governments. The government is already promoting the establishment of these regional clusters and today $26 \%$ of the Israeli population live in areas that are members of some kind of regional clusters cooperating on joint projects. These clusters operate on a voluntary basis and cooperate in a number of domains, such as shared waste management systems, joint procurement tenders and advancing regional education. The government's future plans involve gradual institutionalisation of these clusters so as to specialise in regional issues and promote operations to increase scale. At the same time, the plans also include discussions about transitioning to a multi-layered governmental structure. The metropolitan clusters would inherit responsibilities from the government and from local authorities. Establishing regional and metropolitan clusters could potentially help overcome fractional decision-making, which can delay projects involving several municipalities.

The government should continue with these efforts to enhance cooperation among local governments and should consider providing financial incentives to promote these efforts. In recent years many OECD countries have significantly enhanced municipal co-operation to partially solve municipal fragmentation by taking advantage of economies of scale for investments and service provision. For instance, in Estonia and Norway central government provides additional funds for joint public investments, and Slovenia encourages inter-municipal co-operation by reimbursing $50 \%$ of staff costs of joint management bodies leading to a notable rise in the number of such entities (OECD, 2017e).

In terms of revenues more autonomy for municipalities should be considered. Evidence from other OECD countries suggests that local authorities with substantial tax autonomy have lower tax disparities and that tax autonomy allows poorer municipalities to better foster their economic and fiscal base, making it easier for them to catch up with the national average (Blöchliger and Campos, 2011).

This will require a uniform local tax base. A national audit uncovered substantial deficiencies and a lack of uniformity in the method of levying property taxes by local authorities (TOSC, 2015). It is at present impossible to make tax comparisons between different neighbourhoods or cities. There are too many classifications of property and different rates assigned to each sub-classification. There is currently no uniform method used to calculate the size of homes for tax purposes. Many OECD countries have moved towards a central tax base, thereby leaving less leeway for gaming it (Blöchliger, 2014). The Ministry of Interior has established a joint panel with representatives from different ministries to address the shortcomings of the current system, including by reducing the number of different classifications and subclassifications used for property-tax collection and unifying measurement methods. The panel has been active for two years and has already outlined a draft reform to increase transparency and uniformity of the municipal property tax. 
Table 3. Recommendations for reducing differences between municipalities in Israel

\begin{tabular}{l|l}
\hline \multicolumn{1}{c}{ FINDINGS } & \multicolumn{1}{c}{ RECOMMENDATIONS (key recommendations in bold) } \\
\hline \multicolumn{1}{c}{ Enhance the quality of public transport } \\
\hline $\begin{array}{l}\text { Road traffic intensity is much higher than in other OECD countries. } \\
\begin{array}{l}\text { Congestion causes real damage to the economy and quality of the life of } \\
\text { residents due to the loss of both work and leisure hours and the increase } \\
\text { in air pollution and in road accidents. }\end{array}\end{array}$ & $\begin{array}{l}\text { Introduce congestion charges, accompanied by significant } \\
\text { improvements in the quality of public transport services and } \\
\text { higher parking fees. }\end{array}$ \\
\hline $\begin{array}{l}\text { The coordination in infrastructure governance across levels of } \\
\text { governments is one of the weakest in the OECD. Ineffective coordination } \\
\text { between municipalities often leads to lengthy negotiations that hinder the } \\
\text { advancement of projects. }\end{array}$ & $\begin{array}{l}\text { Establish metropolitan transport authorities in the Tel Aviv area } \\
\text { and perhaps other areas in Israel to promote integrated transport } \\
\text { networks and pricing systems and ensure stable financial support } \\
\text { for public transport. }\end{array}$ \\
\hline $\begin{array}{l}\text { Israel's infrastructure regulation is currently stricter than other countries. } \\
\text { Only half of the total market for bus services is open to competition. }\end{array}$ & $\begin{array}{l}\text { Reduce regulation in public transport by fully opening bus services to } \\
\text { competition. }\end{array}$ \\
\hline
\end{tabular}

Improve housing affordability

Rapid increases in housing prices have exacerbated inequalities and widened regional differences. They have been associated with a growing disparity in housing affordability. Poorer families cannot afford to own an apartment, and the rent burden is high in international comparison, particularly for low-income tenants.

Arab-Israeli municipalities face significant housing challenges. Unregistered housing, which is widespread across Arab-Israeli municipalities, result in a delayed planning and construction process and represents huge tax losses for municipalities.

Eligibility for social housing should be regularly reassessed, should target the most disadvantaged households and should be provided in areas of employment opportunities.

Provide support to formalisation of housing in Arab-Israel municipalities, including legal, financial and technical support.

Improve education in the poorer localities

Weaker municipalities do not have the necessary resources to build new buildings and ensure places for all 3-4 year-olds. Expenditure per pupils in pre-school education is much lower than in other OECD countries.

Teacher quality in areas where many people have a relatively low socioeconomic background is significantly lower than in economically stronger localities, which can further diminish students' chances of success.

The existence of different school streams in Israel reinforces geographic segregation along religious/community lines and hinders mobility. The fragmented education system weakens skills formation and contributes to Israel having the largest dispersion in educational outcomes in the Continue with efforts to increase participation in high-quality pre-school education, and expand day care centres, particularly in poor and disadvantaged localities.

Provide financial and good working conditions to attract the best teachers to disadvantaged schools and poorer regions.

\section{Promote teacher exchanges.}

Increase Hebrew courses in the Arab stream.

Strengthen the core subjects in the curriculum of the Haredi stream.

Reform the funding of local municipalities

There are large differences in public-sector provision between poorer and wealthier municipalities. Differences in resources mean that poorer municipalities can find it difficult to provide adequate services levels for their residents.

Israeli municipalities do not prioritise residential development, despite the pressing need for more housing in the country: the current property tax system creates incentives for them to favour business over residential development.

Income disparities between the richest and poorest localities are among the highest in the OECD and continue to widen.

Strengthen fiscal equalisation within municipalities mainly through higher compensation from wealthier municipalities

Reduce the difference between non-residential and residential property tax rates. Replace the area-based property tax with transparent and uniform system based on property values.

Decrease the number of local authorities by merging municipalities. Enhance cooperation and coordination across regions by promoting regional clusters and shared industrial zones. 


\section{References}

Aguilar Jaber, A. and D. Glocker (2015), "Shifting towards Low Carbon Mobility Systems", International Transport Forum Discussion Papers, No. 2015/17, OECD Publishing, Paris,

Andrews, D., A. Caldera Sánchez and Å. Johansson (2011), "Housing Markets and Structural Policies in OECD Countries", OECD Economics Department Working Papers, No. 836, OECD Publishing, Paris.

Arab Center for Alternative Planning (2017), والبيوت غير المرخصة في البلدات العربية الواقع والمخاطر - المواجهة (Houses without permits in the Arabic municipalities: the reality and risks, management and solutions), unpublished presentation.

Barak, A. (2019),"The Effect of Public Transit on Employment in Israel's Arab Society", Bank of Israel, Discussion Paper Series, No. 2019.03.

Benhenda, A. (2014), "How to Identify Good Teachers? Teacher Evaluations and Student Achievement", Paris School of Economics, mimeo.

Belikoff, M. and S. Agbaria (2015), "From Deficits and Dependence to Balanced Budgets and Independence", Sikkuy, Injazz, Jerusalem - Haifa - Nazareth,

Ben-David, D. (2018), "Overpopulation and demography in Israel: Directions, perceptions, illusions and solutions", Shoresh Institute, Policy Brief, November,

Blass, N. and H. Bleikh (2018), "The determinants of the Educational Budget: per Student and per Class", in State of the Nation Report-Society, Economic Policy in Israel, A. Weiss (ed.), Taub Center for Social Policy Studies in Israel, pp. 179-210.

Blöchliger, H. (2015), "Reforming the Tax on Immovable Property: Taking Care of the Unloved", OECD Economics Department Working Papers, No. 1205, OECD Publishing, Paris

Blöchliger, H. and J. Pinero Campos (2011), "Tax Competition Between Sub-Central Governments", OECD Economics Department Working Papers, No. 872, OECD Publishing, Paris

Bol (2015), "Public Housing in Israel", excerpt from the "Bank of Israel - Annual Report for 2014"

Bol (2017), Annual Report - 2016, March

Bol (2019), Annual Report-2018, March

Bol (2019), Private transportation in Israel: An analysis of developments in the past two decades, Bank of Israel,

Borjas, George J. (2020), "Demographic Determinants of Testing Incidence and COVID-19 Infections in New York City Neighborhoods," National Bureau of Economic Research Working Paper No. w26952

Brender, A. (2007), "Does municipal segregation alleviate the economic disadvantage of Israeli Arabs?: Local tax collection as an indicator", Harry S. Truman Research Institute for the Advancement of Peace, Hebrew University of Jerusalem

Burger, M., E. Meijers and F. Van Oort (2013), "Regional Spatial Structure and Retail Amenities in the Netherlands", Regional Studies, Vol. 48, No. 12, pp. 1972-92, DOI: 10.1080/00343404.2013.783693.

Chernichovsky, D., B. Bisharat, L. Bowers, A. Brill and C. Sharony (2017), "The Health of the Arab Israeli Population", Taub Center for Social Policy Research, Jerusalem

Chetty, R., N. Hendren, P. Kline and E. Saez (2014), "Where is the land of opportunity? The geography of intergenerational mobility in the US", The Quarterly Journal of Economics, Vol.129, Issue 4, pp. 1553-1623.

Chetty, R., J. Friedman and J. Rockoff (2014), "Measuring the Impacts of Teachers I: Evaluating Bias in Teacher Value-Added Estimates", American Economic Review, Vol. 104, No. 9, pp. 2593-2632.

Darling-Hammond, L. (2010), "Organizing for Success: From Inequality to Quality", in The Flat World and Education: How America's Commitment to Equity will Determine our Future, Teachers College Press, New York, pp. 234-77.

Demmou, L. and G. Franco (2020), "Do sound infrastructure governance and regulation affect productivity growth? New insights from firm level data", Paris, OECD 
Eckstein, Z., E. Tolkovsky and N. Tsur (2012), "Are Housing Prices in Israel High Due to Small Housing Inventory?," unpublished working paper, Gazit-Globe Real Estate Institute, IDC Herzliya.

Friedman, Y. (2019), "Private transportation in Israel: analysis of the last two decades' developments". Bank of Israel Collection of policy analysis and research questions.

Fryer, R., Jr. (2017), "The Production of Human Capital in Developed Countries: Evidence from 196 Randomized Field Experiments", in Handbook of Field Experiments, Vol. 2, National Bureau of Economic Research, Amsterdam: North-Holland, pp. 95-322.

Gal, J., S. Madhala and H. Bleich (2017), "Social service budgeting in local authorities", Taub Center, chapter from The State of the Nation Report 2017

Galster, G. ( 2007), "Neighbourhood Social Mix as a Goal of Housing Policy: A Theoretical Analysis", European Journal of Housing Policy, Vol. 7, No. 1, pp. 19-43.

Gatti, R., S. Karacsony, I. Sandor, K. Anan, C. Ferré and C. de Paz Nieves (2016), Being Fair, Faring Better, Promoting Equality of Opportunity for Marginalized Roma, World Bank, Washington, DC.

Gibbons, S. (2002)," Neighbourhood Effects on Educational Achievement: Evidence from the Census and National Child Development Study", Centre for the Economics of Education Discussion Paper, London School of Economics, No. 16.

Globes (2019) "Tel Aviv metro delayed by elections", 3 January

Hadyur Beyeshuvey Hameeutim (The 120 days team report for Dealing with the Housing Issues in Minority Municipalities)

Hanushek, E., J. Kain and S. Rivkin (2004), "Why Public Schools Lose Teachers," Journal of Human Resources, Vol. 39, No. 2.

HoC (2019), "What is affordable housing?", Number 07747, 20 May.

Houlberg, K. et al. (2016), OECD Review of Policies to Improve the Effectiveness of Resource Use in Schools: Country Background Report for Denmark, Det Nationale Institut for Kommuners og Regioners Analyse og Forskning (KORA) [Danish Institute for Local and Regional Government Research], Copenhagen.

Hsieh, C. and E. Moretti (2015), "Why do cities matter? Local growth and aggregate growth", Working Paper, No. w21154, National Bureau of Economic Research.

Ida, Y. and G. Talit (2017a), "Reforms in the regulation of public bus service in Israel", Case Studies on Transport Policy, Vol. 5, Issue 1, March, pp. 80-86

Ida, Y. and G. Talit (2017b), "What we can learn 17 years after the reform in public bus transportation in Israel", Case Studies on Transport Policy,Vol. 6, Issue 4, December, pp. 510-17

IMF (2017) "Israel : 2017 Article IV Consultation", IMF, Washington

Israel Innovation Authority (2018), “Innovation report 2018"

ITF (2018), "Policy Directions for Establishing a Metropolitan Transport Authority for Korea's Capital Region", International Transport Forum Policy Papers, No. 61, OECD Publishing, Paris,

Justman, M. and A. Spivak (2004), "Socioeconomic dynamics of local authorities in Israel", Bank of Israel, Israel Economic Review, Vol. 2, No.1

Khamaisi, R. (2013), "Housing Transformation within Urbanized Communities: The Arab Palestinians in Israel", Geography Research Forum, Vol. 33, pp. 184-209.

Kim, J. and S. Dougherty (eds.) (2018), Fiscal Decentralisation and Inclusive Growth, OECD Fiscal Federalism Studies, OECD Publishing, Paris/KIPF, Seoul

KRIC (2019), "Bilingual Institutions (Hebrew-Arabic) in the Education System", The Knesset Research and Information Center, Jerusalem, January

Krill, Z. and K. Bats (2019) "The Geography of Intergenerational Mobility in Israel” Ministry of Finance of Israel, (fortcomming) 
Machlica, G. (2020), "The Ultra-Orthodox community in Israel", OECD Economics Department Working Paper, forthcoming.

Marom, S. (2015), "The Importance of Learning Hebrew for Integrating and Promoting the Arab Population in the Israeli Job Market", Adult Education in Israel, Vol. 14.

Mijers, E., M. Hoogerbrugge and R. Cardoso (2017). "Beyond Polycentricity: Does Stronger Integration Between Cities in Polycentric Urban Regions Improve Performance?", Tijdschrift voor economische en sociale geografie, DOI: 10.1111/tesg.12292.

Moav, O. and S. Schreiber (2017), "How to reduce congestion on roads by adopting congestion fees", IDC Herzliya, The Aaron Institute for Economic Policy, December,

Mofkadi, T. and R. Shalem (2018), "Reforming the financing of local authorities",IDC Herzliya, Aaron Institute for Economic Policy.

Naáley-Yosef, H. (2011), "Shivuk Karkaot Medina Lepituah Vebnia Beyeshuvim Araviim (Public Land Marketing to developing and construction in Arabic Municipalities)", The Association for the Advancement of Civic Equality, working paper.

National Insurance Institute (2016), Poverty and social gaps report 2015

OECD (2005), Teachers Matter: Attracting, Developing and Retaining Effective Teachers, Education and Training Policy, OECD Publishing, Paris.

OECD (2009a), How Regions Grow: Trends and Analysis, OECD Publishing, Paris

OECD (2009b), "School Evaluation, Teacher Appraisal and Feedback and the Impact on Schools and Teachers", in Creating Effective Teaching and Learning Environments: First Results from TALIS, OECD Publishing, Paris.

OECD (2012), Equity and Quality in Education: Supporting Disadvantaged Students and Schools, OECD Publishing, OECD publishing, Parishttp://dx.doi.org/10.1787/9789264130852-en.

OECD (2013), Fiscal Federalism 2014: Making Decentralisation Work, OECD Publishing.

OECD, (2014a) "Recommendation of the Council on Effective Public Investment Across Levels of Government" OECD Publishing, Paris

OECD (2014b), “How Much Are Teachers Paid and How Much Does it Matter?”, Education Indicators in Focus, No. 21, OECD Publishing, Paris.

OECD (2015), Governing the City, OECD Publishing, Paris.

OECD (2016a), OECD Territorial Reviews: The Metropolitan Region of Rotterdam-The Hague, Netherlands, OECD Territorial Reviews, OECD Publishing, Paris.

OECD (2016b), OECD Economic Surveys: Czech Republic 2016, OECD Publishing, Paris.

OECD (2017a), Spatial Planning and Policy in Israel: The Cases of Netanya and Umm al-Fahm, OECD Publishing, Paris.

OECD (2017b), The Governance of Land Use in OECD Countries: Policy Analysis and Recommendations, OECD Publishing, Paris.

OECD (2017c), OECD Economic Surveys: France 2017, OECD Publishing, Paris.

OECD (2017d), Starting Strong 2017: Key OECD Indicators on Early Childhood Education and Care, OECD Publishing, Paris.

OECD (2017e), Making Decentralisation Work in Chile: Towards Stronger Municipalities, OECD Multilevel Governance Studies, OECD Publishing, Paris.

OECD (2018a), OECD Regions and Cities at a Glance 2018, OECD Publishing, Paris.

OECD (2018b), A Broken Social Elevator? How to Promote Social Mobility, OECD Publishing, Paris.

OECD (2018c), OECD Economic Surveys: Israel 2018, OECD Publishing, Paris.

OECD (2018d), Engaging Young Children: Lessons from Research about Quality in Early Childhood Education and Care, Starting Strong series, OECD Publishing, Paris. 
OECD (2018e), OECD Economic Surveys: Canada 2018, OECD Publishing, Paris.

OECD (2019a), "Assessing incentives to reduce congestion in Israel", OECD Publishing, Paris

OECD (2019b), PISA 2018 Results (Volume II): Where All Students Can Succeed, PISA, OECD

Publishing, Paris,

OECD (2020a) "The territorial impact of COVID-19: managing the crisis across levels of government" OECD Publishing, Paris

OECD (2020b), "A review of local government finance in Israel: reforming the Arnona system", forthcoming.

OECD (2020c) "Comparing fiscal equalisation systems" forthcoming

Pisu, M., B. Pels and N. Bottini (2015), "Improving infrastructure in the United Kingdom", OECD Economics Department Working Papers, No. 1244, OECD Publishing, Paris.

Russo, A., J. van Ommeren and A. Dimitropoulos (2019), "The Environmental and Welfare Implications of Parking Policies", OECD Environment Working Papers, No. 145, OECD Publishing, Paris.

Sampson, R.J. and P. Sharkey (2008), "Neighborhood selection and the social reproduction of concentrated neighborhood inequality", Demography, Vol. 45/1, pp. 1-29.

Santiago, P. et al. (2017), OECD Reviews of School Resources: Chile 2017, OECD Reviews of School Resources, OECD Publishing, Paris.

Scanlon, K. and C. Whitehead (2011), "French social housing in an international context", OECD Economics Department Working Papers, No. 862, OECD Publishing, Paris.

Sharkey, P. (2008), “The intergenerational transmission of context”, American Journal of Sociology, Vol. 113/4, pp. 931-69.

Shavit, Y., I. Friedman, J. Gal and D. Vaknin (2018), "Emerging Early Childhood Inequality: On the Relationship Between Poverty, Sensory Stimulation, Child Development, and Achievement", in State of the Nation, A. Weiss (ed.), Taub Center for Social Policy, Jerusalem.

Shoresh (2020) "Socioeconomic aspects of Coronavirus infection rates across Israeli municipalities, Shoresh Institute

Shraberman, K. and N. Blass (2017), "Household Expenditure on Preschools" State of the Nation, Taub Center for Social Policy, A. Weiss (ed.), Jerusalem.

Shwed, U., Y. Shavit, M. Dellashi and M. Ofek (2014), "Integration of Arab Israelis and Jews In Schools in Israel", State of the Nation Report, D. Ben-David (ed.), Taub Center for Social Policy, Jerusalem.

Suhoy, T. and Y. Sofer (2019) "Getting to Work in Israel: Locality and Individual Effects", Bank of Israel, Research Department.

TOSC (2015), "Municipal Rate (Arnona) - Levying, Discounts and Regulation of Collection", The Office of the State Controller, Local Authorities Report 2015

TOSC (2019), "The Public Transport Crises", The Office of the State Controller.

TomTom (2018), Traffic index ranking 2018.

Tyndall, J. (2017), "Waiting for the R Train: Public Transportation and Employment", Urban Studies, Vol. 54 , No. 2, pp. 520-37.

Waitzberg et al. (2020) "Israel's response to the COVID-19 pandemic: tailoring measures for vulnerable cultural minority populations" International Journal for Equity in Health (2020) 19:71 